\title{
Galectin signatures contribute to the heterogeneity of breast cancer and provide new prognostic information and therapeutic targets
}

\author{
Andrée-Anne Grosset ${ }^{1,2}$, Marilyne Labrie ${ }^{1}$, Maria Claudia Vladoiu ${ }^{1}$, Einas M Yousef ${ }^{2}$, \\ Louis Gaboury ${ }^{2}$, Yves St-Pierre ${ }^{1}$ \\ ${ }^{1}$ INRS-Institut Armand-Frappier, 531 Blv des Prairies, Laval, Quebec H7V 1B7, Canada \\ ${ }^{2}$ IRIC | Université de Montréal, 2950 Chemin de Polytechnique, Montreal, Quebec H3T 1J4, Canada \\ Correspondence to: Yves St-Pierre, e-mail: yves.st-pierre@iaf.inrs.ca
}

Keywords: breast cancer, triple negative, galectins, tissue microarrays, immunohistochemistry

Received: November 05, 2015

Accepted: January 29, 2016

Published: February 27, 2016

\section{ABSTRACT}

Because of their ability to induce local immunosuppression and to confer cancer cells with resistance to apoptosis, members of the galectin family are emerging as a new class of actionable targets in cancer. Unfortunately, we have yet to obtain a clear picture of the galectin signatures in cancer cells and the surrounding tumor microenvironment. The aim of this study was to provide the first detailed analysis of the galectin signature in molecular subtypes of breast cancer. Expression signatures of galectins were obtained at the mRNA and protein levels. A particular attention was paid to stromal versus epithelial staining and to subcellular compartmentalization. Analysis of the stromal signature showed that gal-1, -3, -9-positive stroma were preferentially found in triple-negative (TN) and HER2 subtypes. In cancer cells, gal-1, $-3,-8$, and -9 showed a dual expression pattern, being found either in the cytosol or in the cytosol and the nucleus. TN patients with gal-8-positive nuclei had significantly better disease-free survival (DFS), distant-disease-free survival (DDFS), and overall survival (OS). In contrast, high expression of nuclear gal-1 correlated with poor DDFS and OS. TNBC patients who were positive for both nuclear gal-1 and gal-8 had 5 -year DFS and DDFS of $100 \%$, suggesting a dominance of the gal-8 phenotype. Overall, the results indicate that specific galectin expression signatures contribute to the phenotypic heterogeneity of aggressive subtypes of breast cancer. Our data also suggest that galectins have clinical utility as indicators of disease progression and therapeutic targets in aggressive molecular subtypes of breast cancer.

\section{INTRODUCTION}

Gene profiling studies have greatly helped at better classifying breast cancer into at least four generally recognized molecular subtypes. Clinically, these molecular subtypes are identified based on the immunohistochemical expression of the estrogen (ER) and progesterone (PR) receptors and of Human Epidermal Growth Factor Receptor 2 (HER2), a member of the epidermal growth factor receptor family. These molecular subtypes include luminal $\mathrm{A}$ and $\mathrm{B}, \mathrm{HER} 2$-positive, and triple negative breast cancer (TNBC; ER-, PR-, and HER2-negative tumor) $[1,2]$. Because they lack actionable targets, TNBC and HER2-positive subtypes are thus untreatable with hormone therapies and have a very poor prognosis.
The heterogeneity of HER2 and TNBCs at the molecular and cellular levels represents, however, a formidable obstacle to the development of new treatment modalities of these aggressive subtypes [3,4]. Such challenge is further complicated by the complexity of the tumor microenvironment (TME) which plays a critical role in the disease progression [5].

Carbohydrate-dependent interactions are critical in many physiological processes as well as in pathological abnormalities, most notably in cancer. Outside the cells, these interactions are well known to facilitate intercellular communications, increasing the stability of growth receptors via lattice formation, and modulating the immune response following binding to cell surface receptors [6]. Inside the cells, they modulate signaling 
cascades, direct trafficking of proteins or contribute to the regulation of gene expression by binding to transcription factors or proteins involved in mRNA splicing [7].

In cancer, such carbohydrate-dependent interactions are mediated in a large part by galectins, an evolutionarily ancient family of soluble proteins that bind N-linked and O-linked beta-galactosides via a conserved Carbohydrate Recognition Domain (CRD). Galectins were first isolated from chick muscle and calf heart and lungs and have since been named in the order of discovery $[8,9]$. The 15 members of the family are generally classified according to the number and structure of their CRD. Galectins are therefore divided into tandem, dimeric and chimeric galectins. Dimeric galectins (galectins-1, -2, -5, -7, -10, $-11,-13,-14$ and -15$)$ have two identical CRD subunits while tandem ones (galectins-4, $-6,-8,-9$ and -12) have two distinct CRD subunits. Galectin-3 is the only chimeric galectin discovered in mammals thus far. Galectins- 5 and -6 are found only in rodents. There is compelling evidence, however, that prototypic galectins might have non-carbohydrate binding partners and functions (reviwed in reference 7). These CRD-independent functions represent a paradigm shift in our understanding of galectin functions.

Our knowledge on the role of galectins in cancer and as biomarkers of disease progression has attracted the interest of many, most notably because these small molecular weight proteins undergo significant changes in their pattern of expression during progression of cancer. Their role in cancer progression, however, is not lacking in subtlety [10]. While cancer progression in accelerated by some galectins, others clearly inhibit tumor growth and/or formation of metastasis. Moreover, there is increasing evidence that galectins function as alarmins [11]. In response to aggression, they are released via a non-classical secretion pathway in the extracellular space where they play a critical role in controlling the immune response. Such complexity in their behavior represents a true challenge when developing galectin inhibitors or use their expression pattern as predictive biomarkers. Moreover, while most studies have examined one galectin at a time, focusing largely on galectin-1 and galectin-3, it is now well established that normal and tumor cells express more than one galectins, and that multiple galectins could be released in the tumor microenvironment (TME) $[12,13]$. Defining a galectin signature for specific subtypes is thus critical to identify new therapeutic targets in concert with companion diagnostics and/or molecular signatures to guide therapeutic decisions. In the present work, we have examined the expression of seven galectins in breast cancer tissues by immunohistochemistry and correlated their expression with the different molecular subtypes of breast cancer.

\section{RESULTS}

\section{In silico analysis of galectin mRNA expression in breast cancer tissues}

We first used the prognostic module of the Breast Cancer Gene-Expression Miner v3.1 (bc-GenExMiner) public database to investigate galectin expression at the mRNA level among breast cancer molecular subtypes. For each subtype, an expression map containing the percentage of patients with low, intermediate, and high gene expression for gal-1, $-2,-3,-4,-7,-8$, and -9 was retrieved. Gene expression values were being beforehand split in order to form three equal groups so that "high expression" represents the $1 / 3$ of the patients with highest expression of a gene and "low expression" is the lower $1 / 3$ of the patients. For example, a representative schematic diagram for lgals1 shows that lgals1 expression measured in 1260 samples is at its highest in $41 \%$ of patients with basal-like breast and HER2 subtypes of breast cancer (Figure 1A). The diagrams for other members of the galectin family are shown in Supplementary Figure S1. Overall, we found that the relative expression of galectins among the different molecular subtype had a similar distribution, although the percentage of patients with the highest expression of $\operatorname{lgals} 8$, and to a lesser extent $\lg$ als3, were lower in patients with a basal-like subtype (Figure 1B).

We next performed an mRNA survival analysis for each galectin using the Breastmark $R N A$ expression database and algorithm that facilitate investigation of prognostic markers in the context of disease-free survival (DFS), distant disease-free survival (DDFS) and overall survival (OS) [14]. An initial search was performed for breast cancer as a whole, independently of the lymph node status and across the molecular subtypes classified according the PAM50 molecular classifier [15]. Generation of Kaplan-Meier surviving plots showed no significant differences of DFS between groups of patients with high or low expression level of genes encoding gal-2, $-3,-4,-7,-8$, and -9 (Supplementary Figure S2). The only notable difference was seen in patients with higher expression of mRNA level of lgals1. These patients had a significantly lower $(p=0.016)$ DFS than patients with negative/low levels of lgals1, consistent with previous observations that galectin-1 expression correlates with a poor prognosis in breast cancer [16]. High expression of lgals 1 is indeed a poor prognostic factor for both lymph node (LN)-positive and negative breast cancer (Table 1).

We next focused on aggressive molecular subtypes for which new prognostics are needed. In the case of HER2 molecular subtype, we found that patients with high lgals 3 gene expression had a significantly $(p=0.031)$ lower OS than patients with lower levels of lgals3 (Figure 2). 
In contrast, high lgals2 expression was associated with a good DFS, although the difference fell just short of the traditional definition of statistical significance (0.064). A similar trend was observed for $\operatorname{lgals} 2$ and $\operatorname{lgals} 9$ in patients with triple-negative breast cancer (Figure 3). High expression levels of lgals2 $(p=0.031), \operatorname{lgals} 4(p=0.061)$ and $\operatorname{lgals} 9(p=0.008)$ were all good prognostic factors for LN-negative patients (Table 2). Lgals9 $(p=0.004)$ was also a good prognostic factor for patients with luminal $\mathrm{B}$ subtype. Similar results were obtained using the ssp2006 as a classifier [17] (Data not shown). Overall, these results indicate that expression of galectins at the mRNA level can be either a good or bad prognostic markers for patients with aggressive subtypes of breast cancer.

\section{Galectin protein signature in normal and cancerous breast tissues}

We next studied the expression of galectins at the protein level by immunohistochemistry (IHC) using tissue microarrays (TMAs) constructed from 213 human breast cancer tumor tissues representative of each molecular

A

LGALS1 expression map
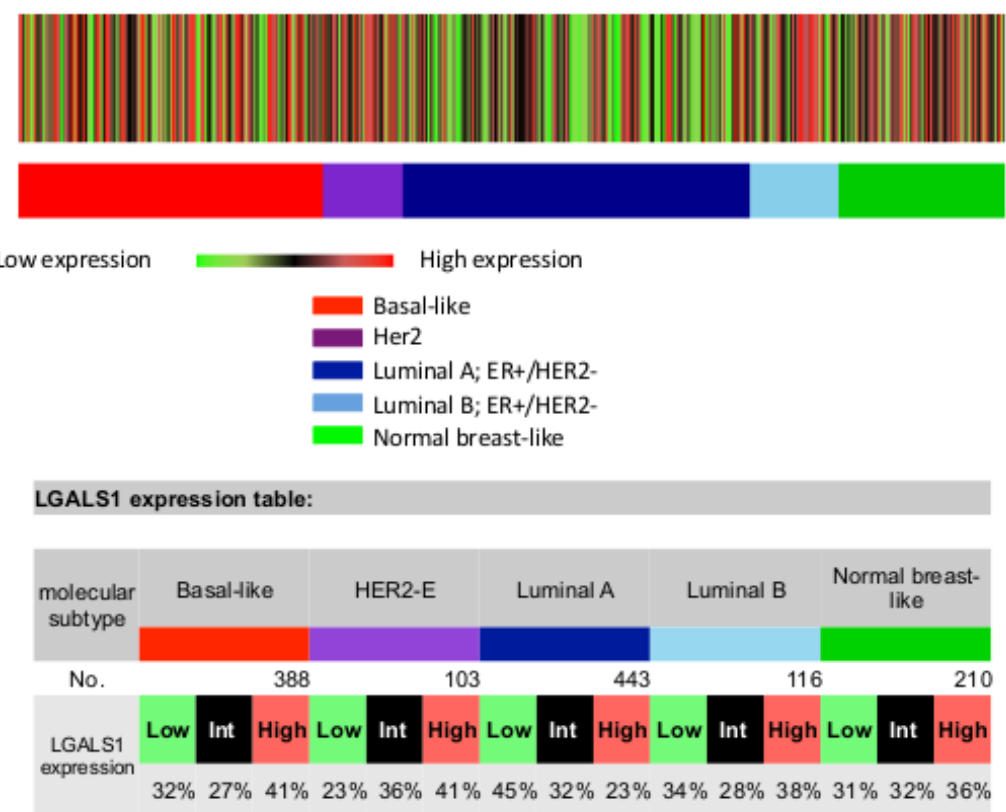

B
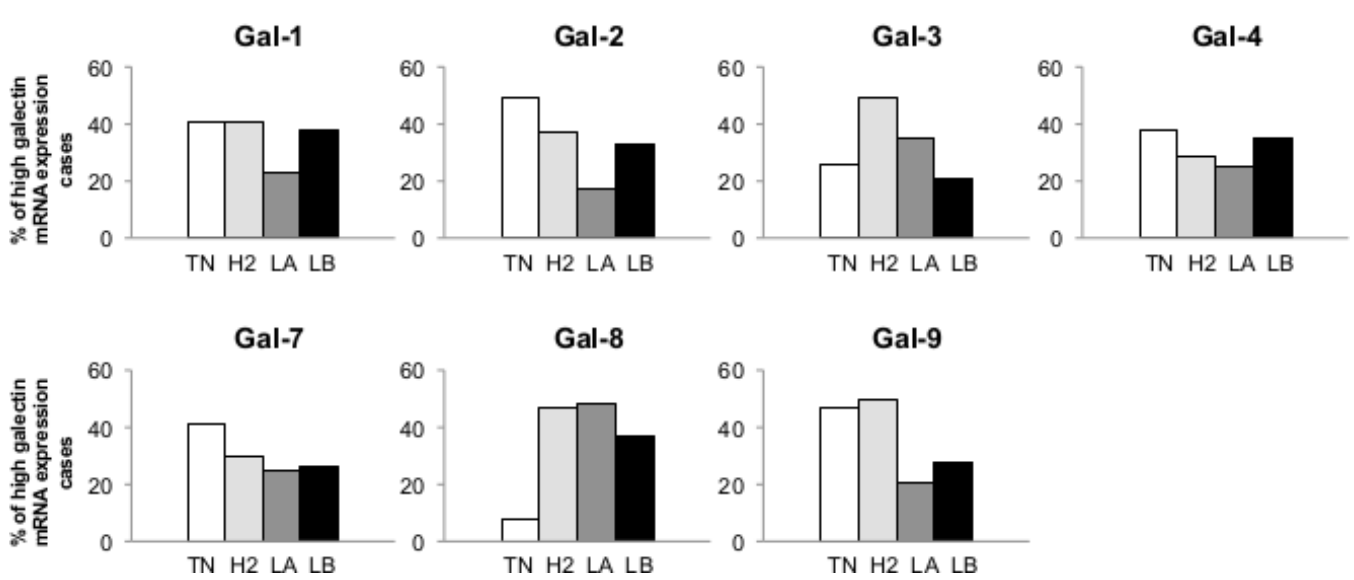

Figure 1: Gene expression map of lgals1 in PAM50 molecular subtypes of breast cancer using bc-GenExMiner database. (A) The map shows the percentage of patients with low, medium and high expression of lgals 1 mRNA in each molecular subtype: Basal-like (ER-, HER-2-), HER-2E (HER-2 enriched), Luminal A (ER+, HER-2-, low proliferation) and Luminal B (ER+, HER-2-, high proliferation). The number of patients for each subtypes is shown. (B) The distribution for lgals1, lgals2, lgals3, lgals4, lgals 7 , lgals 8 , and lgals 9 in each molecular subtypes. 
Table 1: High mRNA expression as a poor prognotic factor for DFS using the pam50 classifier

\begin{tabular}{|c|c|c|c|c|c|c|c|c|c|c|c|c|c|c|}
\hline \multirow{2}{*}{ Gene } & \multicolumn{2}{|c|}{ Across } & \multicolumn{2}{|c|}{ LN-pos } & \multicolumn{2}{|c|}{ LN-neg } & \multicolumn{2}{|c|}{$\operatorname{Lum} \mathbf{A}$} & \multicolumn{2}{|c|}{ Lum B } & \multicolumn{2}{|c|}{ HER2 } & \multicolumn{2}{|c|}{ Basal } \\
\hline & $n$ & $P$ & $n$ & $P$ & $n$ & $P$ & $n$ & $P$ & $n$ & $P$ & $n$ & $P$ & $n$ & $P$ \\
\hline Lgals1 & 2652 & 0.016 & 744 & 0.049 & 1183 & 0.044 & 823 & 0.410 & 1013 & 0.614 & 286 & 0.452 & 424 & 0.047 \\
\hline Lgasl3 & 2601 & 0.031 & 714 & 0.546 & 1161 & 0.100 & 811 & 0.663 & 998 & 0.313 & 275 & 0.031 & 412 & 0.637 \\
\hline Lgals 7 & 455 & 0.245 & 173 & 0.163 & 173 & 0.864 & 153 & 0.038 & 146 & 0.200 & 66 & 0.965 & 72 & 0.220 \\
\hline Lgals8 & 2497 & 0.726 & 672 & 0.218 & 1105 & 0.613 & 783 & 0.699 & 950 & 0.604 & 273 & 0.294 & 407 & 0.794 \\
\hline
\end{tabular}

Her-2-positive BC
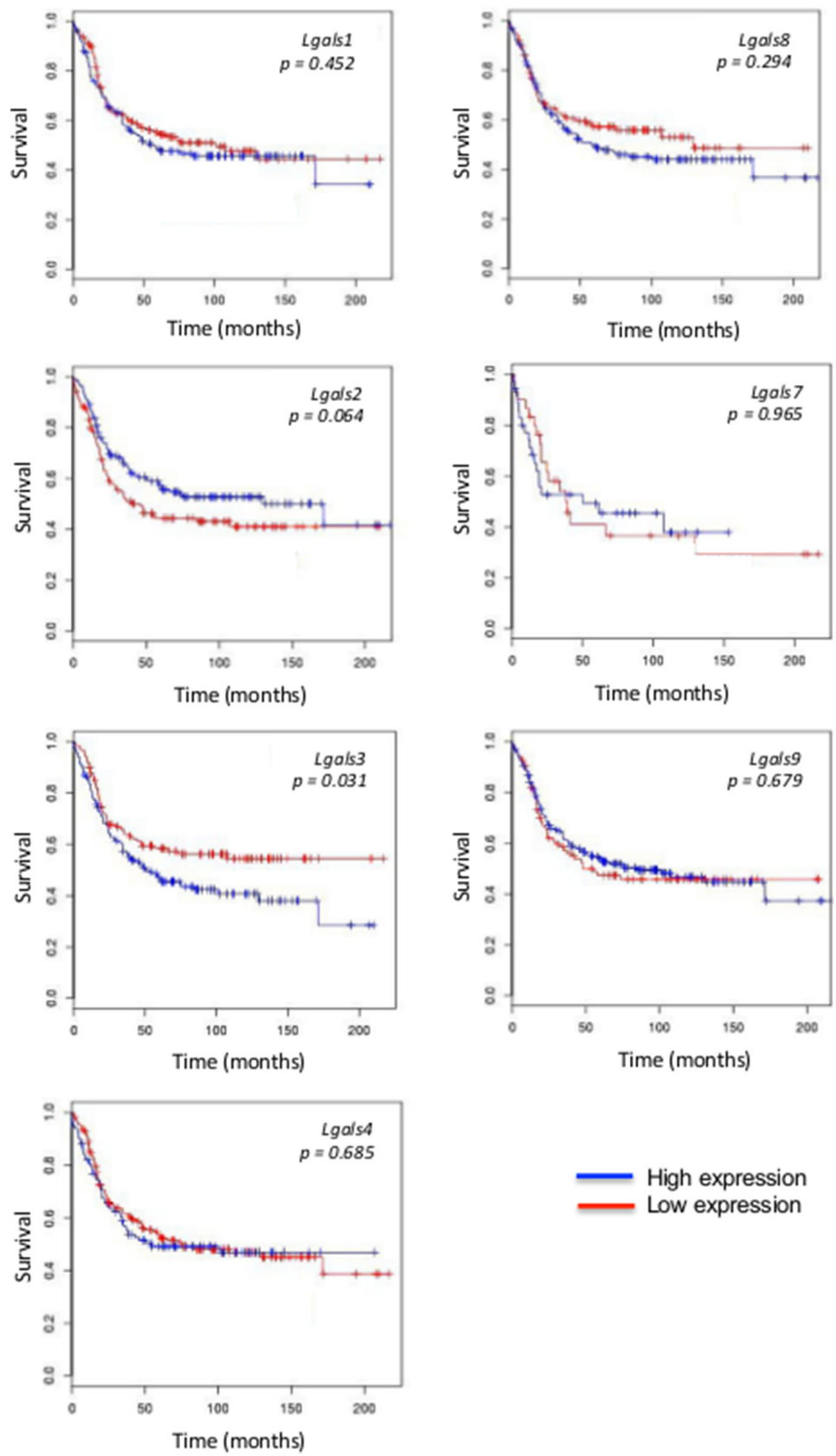

High expression Low expression

Figure 2: Prognostic role of galectin genes in HER2 breast cancer. Kaplan-Meier estimates of overall survival in HER2 patients expressing low or high galectin expression. These figures were generated using BreastMark public database. 
subtypes of breast cancer defined based on ER/PR/ HER2 status and with clinical data. We first validated the specificity of the IHC reactivity of the commercial antibodies using information from the Human Protein Atlas $[18,19]$ and a review of the literature (Supplementary Table S1). Representative positive IHC staining of tissues for each selected antibody showed a complete agreement with the predictions (Supplementary Figure S3). Once validated, the antibodies were used to examine expression of galectins in normal breast tissues. Our results showed that gal-2 and gal-4 were only weakly expressed in normal breast tissues, with very weak cytoplasmic staining in luminal cells (Figure 4). Also in normal tissues, we found a moderate/high cytoplasmic and/or nuclear staining for all galectins except gal-7, which showed its typical cytoplasmic and nuclear staining in myoepithelial cells [20] (Table 3). Gal-9 staining revealed a cytoplasmic staining in luminal epithelial cells. Some isolated stromal and epithelial cells were also strongly reactive in the nucleus. These patterns of expression in normal breast tissue were, for most galectins, significantly altered in breast cancer tissues. High levels of galectin expression were observed across all molecular subtypes, except for gal-7, which staining was restricted to HER2 and

\section{TN breast cancer}
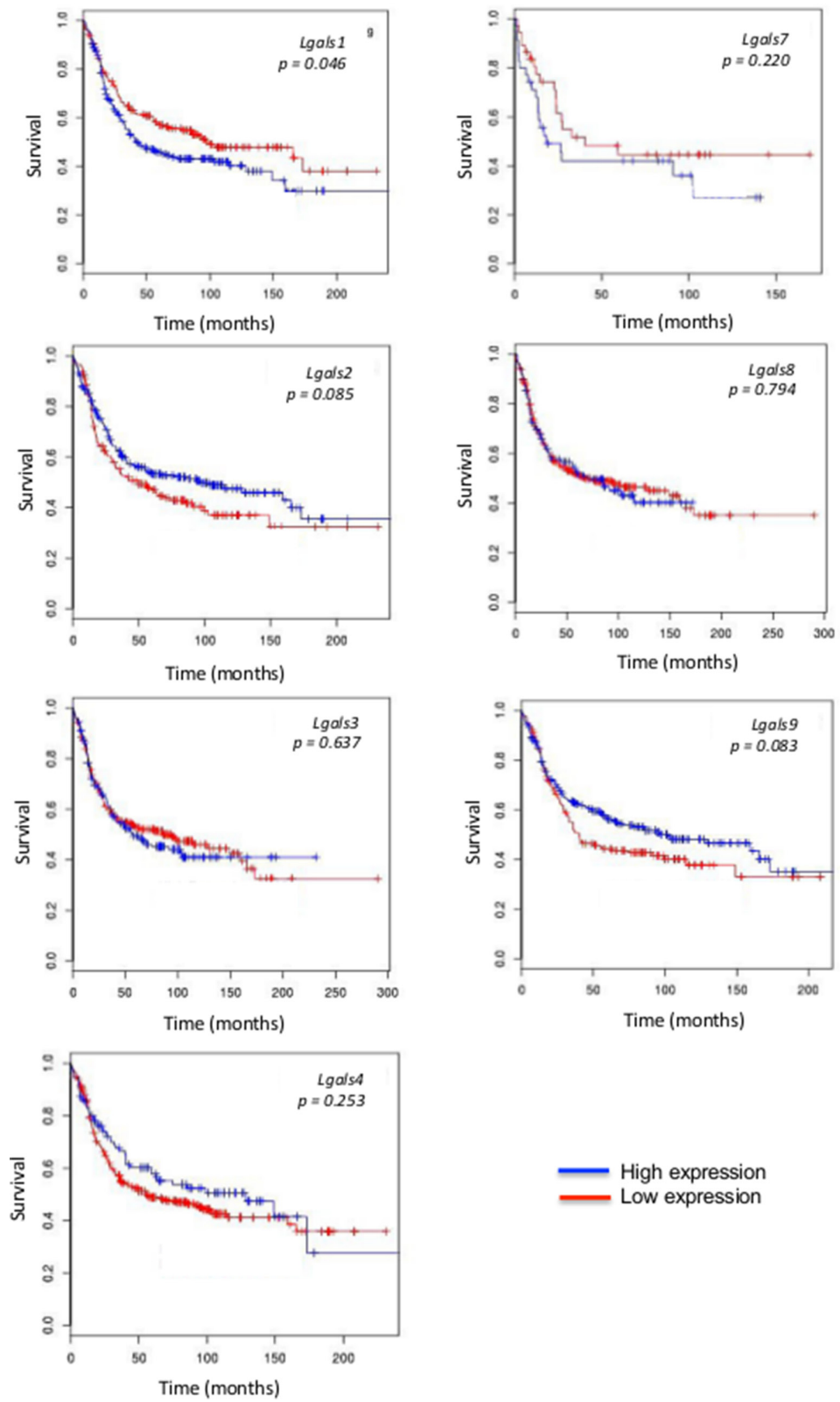

Figure 3: Prognostic role of galectin genes in triple-negative breast cancer. Kaplan-Meier estimates of OS in TNBC patients expressing low or high galectin expression. These figures were generated using BreastMark public database. 
Table 2: High mRNA expression as a good prognotic factor for DFS using the pam50 classifier

\begin{tabular}{c|c|c|c|c|c|c|c|c|c|c|c|c|c|c|c|c|}
\hline \multirow{2}{*}{ Gene } & \multicolumn{4}{c}{ Across } & \multicolumn{1}{c}{ LN-pos } & \multicolumn{1}{c}{ LN-neg } & \multicolumn{1}{c}{ Lum A } & \multicolumn{1}{c}{ Lum B } & \multicolumn{1}{c}{ HER2 } & \multicolumn{2}{c}{ Basal } \\
\cline { 2 - 17 } & $\boldsymbol{n}$ & $\boldsymbol{P}$ & $\boldsymbol{n}$ & $\boldsymbol{P}$ & $\boldsymbol{n}$ & $\boldsymbol{P}$ & $\boldsymbol{n}$ & $\boldsymbol{P}$ & $\boldsymbol{n}$ & $\boldsymbol{P}$ & $\boldsymbol{n}$ & \multicolumn{1}{c}{$\boldsymbol{P}$} & \multicolumn{1}{c}{$\boldsymbol{n}$} & $\boldsymbol{P}$ \\
\hline Lgals2 & 2952 & 0.558 & 719 & 0.998 & 1155 & $\mathbf{0 . 0 3 1}$ & 807 & 0.795 & 987 & 0.732 & 275 & 0.064 & 419 & $\mathbf{0 . 0 8 5}$ \\
\hline Lgals4 & 2652 & 0.281 & 744 & 0.537 & 1183 & $\mathbf{0 . 0 6 1}$ & 823 & 0.449 & 1013 & 0.353 & 286 & 0.685 & 424 & 0.253 \\
\hline Lgals9 & 2652 & 0.350 & 744 & 0.393 & 1183 & $\mathbf{0 . 0 0 8}$ & 823 & 0.562 & 1013 & $\mathbf{0 . 0 0 4}$ & 286 & 0.679 & 424 & $\mathbf{0 . 0 8 3}$ \\
\hline
\end{tabular}

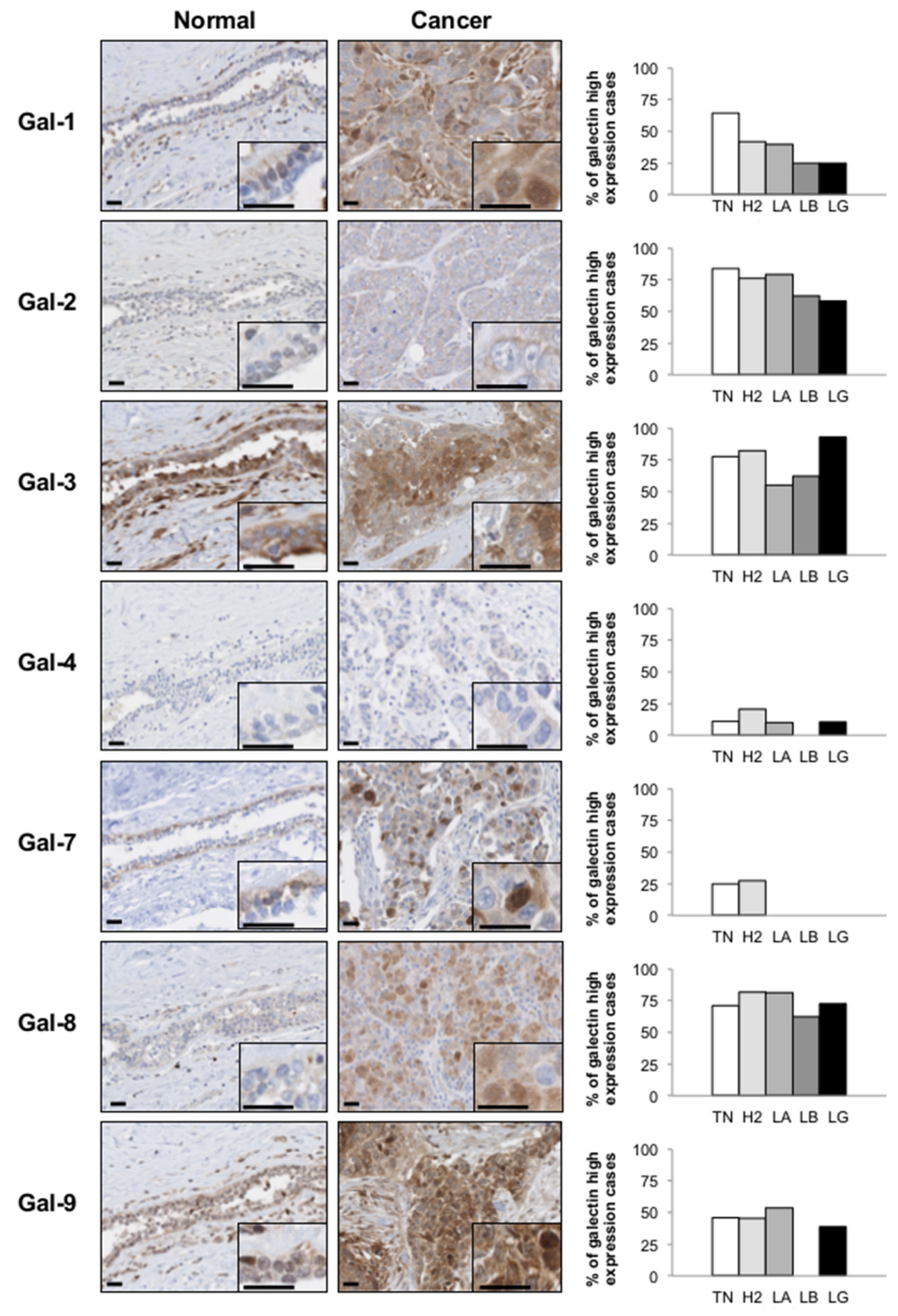

Figure 4: Galectins expression in normal mammary gland and breast cancer tissues. Left panels, representative images of galectin expression in normal mammary and breast cancer tissues. The histograms on the right represent the percentage of molecular subtypes expressing high levels for each galectin: TN (triple-negative; ER-, PR-, HER-2-), H2 (HER-2 positive; ER-, PR-, HER-2+), LA (Luminal A; ER+, HER-2-), LB (Luminal B; ER+, HER-2+). LG (low grade). All scale bars $25 \mu \mathrm{m}$. 
Table 3: Galectins distribution, cellular localization and intensity in normal mammary gland

\begin{tabular}{|c|c|c|c|c|c|}
\hline & \multicolumn{3}{|c|}{ Breast epithelial cells } & \multicolumn{2}{|c|}{ Stroma } \\
\hline & Luminal cells & Myoepithelial cells & Intensity & Localization & Intensity \\
\hline Gal-1 & - & $\mathrm{c}, \mathrm{n}$ & moderate & $\mathrm{e}, \mathrm{c}, \mathrm{n}$ & high \\
\hline Gal-2 & $\mathrm{c}$ & - & weak & $\mathrm{e}, \mathrm{c}$ & moderate \\
\hline Gal-3 & $\mathrm{c}$ & $\mathrm{c}$ & high & $\mathrm{e}, \mathrm{c}, \mathrm{n}$ & high \\
\hline Gal-4 & $\mathrm{c}$ & - & weak & $\mathrm{c}$ & weak \\
\hline Gal-7 & - & $\mathrm{c}, \mathrm{n}$ & moderate & - & - \\
\hline Gal-8 & $\mathrm{c}$ & $\mathrm{c}$ & moderate & $\mathrm{e}, \mathrm{c}$ & moderate \\
\hline Gal-9 & $\mathrm{c}$ & $\mathrm{c}, \mathrm{n}$ & moderate & $\mathrm{e}, \mathrm{c}, \mathrm{n}$ & high \\
\hline
\end{tabular}

Abbreviations: c, cytoplasmic; n, nuclear; e, extracellular.

triple-negative breast cancer (TNBCs). Gal-1-positive staining was also preferentially expressed in TNBCs subtype whereas expression of gal-2, -3, -4, -8, and -9 showed an almost equal distribution in all subtypes, although we could not find any gal-9 positive luminal B samples (Table 4). High levels of gal-1 also showed a significant correlation with $\mathrm{Ki}-67$-positive $(p=0.048)$ staining. Generation of Kaplan-Meier surviving plots showed that high expression levels of gal-3 $(p=0.0548)$ and gal-7 ( $p=0.0786)$ were associated with a worse DFS across the molecular subtypes although the differences barely missed the commonly acceptable statistical significance of $p=0.05$ (Figure 5). In the case of gal3 , however, this difference was statistically significant ( $n=68, p=0.0327$ ) for TNBC (data not shown). Moreover, high expression levels of gal-3 in TNBC patients correlated $(p<0.05)$ with recurrence (Supplementary Table S2).

\section{Cellular localization of galectins in breast cancer cells}

Because previous studies have shown that galectin functions depends on its subcellular localization [21, 22], we examined the subcellular distribution of galectins in breast cancer cells and its association with tumor progression. We found that gal-1, $-3,-8$, and -9 have a dual expression patterns in breast cancer cells. Their expression is either restricted to the cytoplasmic compartments or found in the cytoplasm and the nucleus in the same cell (Figure 6). We found no evidence of nuclear localization of gal-2 and gal-4, in contrast to gal-7, which is almost always found in both nuclear and cytoplasmic compartments in the same cell (Figure 4).

\section{Prognostic values of subcellular galectins}

In the case of gal-1 and gal-2, their respective nuclear and membrane localization correlated with
TNBCs (Table 5). In contrast, gal-8 nuclear expression was preferentially found in low grade breast tumor and significantly $(p<0.0001)$ less frequent in TNBCs. Membrane-associated gal-2 $(p=0.039)$ also correlated with high expression of Ki-67. In fact, in TNBC, patients with gal-8-positive nuclear staining had significantly better DFS $(p=0.0243)$, DDFS $(p=0.0019)$, and OS $(p=0.0292)$ (Figure 7). Such correlation was also observed independently of the molecular subtype (Supplementary Figure S4). In contrast, high expression of nuclear gal-1 correlated with a worst DDFS $(p=0.0080)$ and OS $(p=0.0294)$ in TNBC (Figure 8). Interestingly, patients who were positive for both nuclear gal-1 and nuclear gal-8 had an actual 5-year DFS and DDFS of $100 \%$.

\section{Stromal galectin expression in stromal cells of the tumor microenvironment}

There is increasing evidence that the tumor microenvironment is a key contributor to tumor progression [5]. We have thus examined whether galectins are expressed in stromal cells of the tumor microenvironment. We found that gal-1, -3 , and -9 are commonly found in cells surrounding the tumor, while expression of other galectins were mostly associated with epithelial cancer cells (Figure 9A). In many cases, staining for gal-1, -3 , or -9 were found in both epithelial and stromal cells (approximately $50 \%$ in the case of gal-1 and gal-9 and $75 \%$ in the case of gal-3). In other cases, we could clearly distinguish two clear patterns of staining with these galectins, i.e. that gal-1, -3 , and -9 expression were either strictly found in epithelial tissues or in stromal cells. Gal-1, -3, -9-positive stroma were preferentially found in tumours from TN and HER2 patients (Figure 9B) and correlated with EGFR-positive, Ki67-positive, and mutated p53 (Table 6). Overall, we found that 22 patients were positive for all three galectins (Table 7). All were high grade tumors or were classified as TNBC/ HER2 molecular subtypes. We also found a statistically 
Table 4: Histoclinical correlations of breast cancers according to galectins expression in cancer cells

\begin{tabular}{|c|c|c|c|c|c|c|c|c|c|c|c|c|c|c|}
\hline & \multicolumn{2}{|c|}{ Gal-1 \%(n) } & \multicolumn{2}{|c|}{ Gal-2 \%(n) } & \multicolumn{2}{|c|}{ Gal-3 \%(n) } & \multicolumn{2}{|c|}{ Gal-4 \%(n) } & \multicolumn{2}{|c|}{ Gal-7 \%(n) } & \multicolumn{2}{|c|}{ Gal-8 \%(n) } & \multicolumn{2}{|c|}{ Gal-9 \%(n) } \\
\hline & $\begin{array}{l}\text { Neg/ } \\
\text { Low }\end{array}$ & High & $\begin{array}{l}\text { Neg/ } \\
\text { Low }\end{array}$ & High & $\begin{array}{l}\text { Neg/ } \\
\text { Low }\end{array}$ & High & $\begin{array}{l}\text { Neg/ } \\
\text { Low }\end{array}$ & High & $\begin{array}{l}\text { Neg/ } \\
\text { Low }\end{array}$ & High & $\begin{array}{l}\text { Neg/ } \\
\text { Low }\end{array}$ & High & $\begin{array}{l}\text { Neg/ } \\
\text { Low }\end{array}$ & High \\
\hline $\begin{array}{l}\text { Molecular } \\
\text { subtype }\end{array}$ & \multicolumn{2}{|c|}{$P=0.001$} & & & & & & & \multicolumn{2}{|c|}{$P<0.0001$} & & & & \\
\hline Triple neg & $14(26)$ & $25(47)$ & $6(12)$ & $33(62)$ & $\begin{array}{c}9 \\
(16)\end{array}$ & $\begin{array}{c}30 \\
(56)\end{array}$ & $36(66)$ & $4(8)$ & $29(54)$ & $10(18)$ & $12(21)$ & $29(52)$ & $21(39)$ & $18(33)$ \\
\hline HER-2 & $10(18)$ & 7 (13) & $4(8)$ & $14(26)$ & $3(6)$ & $\begin{array}{c}15 \\
(28)\end{array}$ & $15(27)$ & $4(7)$ & $13(24)$ & $5(9)$ & $3(6)$ & $15(27)$ & $10(18)$ & $8(15)$ \\
\hline $\begin{array}{l}\text { Luminal } \\
\text { A }\end{array}$ & $26(48)$ & $13(24)$ & $\begin{array}{c}11 \\
(21)\end{array}$ & $26(49)$ & $\begin{array}{c}11 \\
(20)\end{array}$ & $\begin{array}{c}27 \\
(50)\end{array}$ & $33(62)$ & $4(7)$ & $39(71)$ & $0(0)$ & $8(15)$ & $29(52)$ & $20(37)$ & $18(33)$ \\
\hline $\begin{array}{l}\text { Luminal } \\
\text { B }\end{array}$ & $3(6)$ & $1(2)$ & $2(3)$ & $3(5)$ & $2(3)$ & $3(5)$ & $4(8)$ & $0(0)$ & $4(8)$ & $\mathbf{0}(\mathbf{0})$ & $2(3)$ & $3(5)$ & $4(8)$ & $0(0)$ \\
\hline $\begin{array}{l}\text { SBR-EE } \\
\text { Grade }\end{array}$ & \multicolumn{2}{|c|}{$P=0.006$} & \multicolumn{2}{|c|}{$P=0.02$} & \multicolumn{2}{|c|}{$P=0.017$} & & & \multicolumn{2}{|c|}{$P=0.005$} & & & & \\
\hline I (low) & $14(24)$ & $5(8)$ & $8(13)$ & $11(18)$ & $1(2)$ & $\begin{array}{c}16 \\
(28)\end{array}$ & $15(26)$ & $2(3)$ & $18(31)$ & $0(0)$ & $5(8)$ & $12(21)$ & $11(19)$ & $7(12)$ \\
\hline III (high) & $39(67)$ & $42(72)$ & $\begin{array}{c}17 \\
(29)\end{array}$ & $\begin{array}{c}65 \\
(112)\end{array}$ & $\begin{array}{c}23 \\
(39)\end{array}$ & $\begin{array}{c}60 \\
(102)\end{array}$ & $\begin{array}{c}74 \\
(127)\end{array}$ & $9(15)$ & $66(113)$ & $16(27)$ & $21(36)$ & $\begin{array}{c}62 \\
(104)\end{array}$ & $46(78)$ & $36(62)$ \\
\hline \multicolumn{15}{|l|}{ Age, yr } \\
\hline$\leq 45$ & $9(16)$ & $11(20)$ & $5(9)$ & $15(27)$ & $4(8)$ & $\begin{array}{c}15 \\
(27)\end{array}$ & $16(30)$ & $4(7)$ & $16(30)$ & $4(7)$ & $3(5)$ & $16(29)$ & $12(22)$ & $8(15)$ \\
\hline$>45$ & $44(81)$ & $36(66)$ & $\begin{array}{c}19 \\
(35)\end{array}$ & $\begin{array}{c}62 \\
(114)\end{array}$ & $\begin{array}{c}20 \\
(37)\end{array}$ & $\begin{array}{c}61 \\
(111)\end{array}$ & $\begin{array}{c}72 \\
(132)\end{array}$ & $8(15)$ & 69 (126) & $11(20)$ & $22(39)$ & $\begin{array}{c}59 \\
(107)\end{array}$ & $43(79)$ & $36(66)$ \\
\hline \multicolumn{15}{|l|}{$\begin{array}{l}\text { Tumor } \\
\text { volume }\end{array}$} \\
\hline$\leq 10 \mathrm{~cm}^{3}$ & $31(52)$ & $26(44)$ & $\begin{array}{c}14 \\
(23)\end{array}$ & $42(72)$ & $\begin{array}{c}12 \\
(20)\end{array}$ & $\begin{array}{c}44 \\
(75)\end{array}$ & $47(80)$ & $8(14)$ & $49(84)$ & $7(12)$ & $13(21)$ & $45(75)$ & $31(52)$ & $25(43)$ \\
\hline$>10 \mathrm{~cm} 3$ & $21(36)$ & $22(37)$ & $\begin{array}{c}10 \\
(17)\end{array}$ & $35(59)$ & $\begin{array}{c}14 \\
(24)\end{array}$ & $\begin{array}{c}30 \\
(52)\end{array}$ & $41(70)$ & $4(7)$ & $37(62)$ & $7(12)$ & $13(21)$ & $30(51)$ & $23(39)$ & $21(35)$ \\
\hline \multicolumn{15}{|l|}{$\begin{array}{l}\text { Lymph } \\
\text { node } \\
\text { metastasis }\end{array}$} \\
\hline Negative & $32(58)$ & $32(58)$ & $\begin{array}{c}13 \\
(23)\end{array}$ & $51(93)$ & $\begin{array}{c}15 \\
(26)\end{array}$ & $\begin{array}{c}49 \\
(87)\end{array}$ & $\begin{array}{c}57 \\
(102)\end{array}$ & $6(11)$ & $56(101)$ & 7 (13) & $15(27)$ & $48(85)$ & $35(62)$ & $28(50)$ \\
\hline Positive & $20(35)$ & $16(28)$ & $\begin{array}{c}11 \\
(19)\end{array}$ & $25(46)$ & $\begin{array}{c}9 \\
(16)\end{array}$ & $\begin{array}{c}28 \\
(50)\end{array}$ & $31(56)$ & $6(11)$ & $29(52)$ & 7 (13) & $9(15)$ & $28(49)$ & $20(35)$ & $17(31)$ \\
\hline ER & \multicolumn{2}{|c|}{$P=0.004$} & & & & & & & \multicolumn{2}{|c|}{$P<0.0001$} & & & & \\
\hline Neg/Low & $27(50)$ & $34(62)$ & $\begin{array}{c}12 \\
(22)\end{array}$ & $51(94)$ & $\begin{array}{c}12 \\
(22)\end{array}$ & $\begin{array}{c}50 \\
(92)\end{array}$ & $\begin{array}{c}55 \\
(101)\end{array}$ & $8(15)$ & 47 (86) & $15(27)$ & $17(31)$ & $45(82)$ & $34(62)$ & $27(50)$ \\
\hline High & $26(48)$ & $13(24)$ & $\begin{array}{c}12 \\
(22)\end{array}$ & $26(48)$ & $\begin{array}{c}13 \\
(23)\end{array}$ & $\begin{array}{c}26 \\
(47)\end{array}$ & $34(62)$ & $4(7)$ & $39(71)$ & $0(0)$ & $8(14)$ & $30(54)$ & $22(40)$ & $17(31)$ \\
\hline PR & \multicolumn{2}{|c|}{$P=0.034$} & & & & & & & \multicolumn{2}{|c|}{$P=0.029$} & & & & \\
\hline Neg/ Low & $43(79)$ & $43(79)$ & $\begin{array}{c}20 \\
(38)\end{array}$ & $\begin{array}{c}66 \\
(123)\end{array}$ & $\begin{array}{c}22 \\
(40)\end{array}$ & $\begin{array}{c}65 \\
(119)\end{array}$ & $\begin{array}{c}76 \\
(141)\end{array}$ & $\begin{array}{c}10 \\
(19)\end{array}$ & 72 (132) & $15(27)$ & $22(40)$ & $\begin{array}{c}65 \\
(118)\end{array}$ & $49(90)$ & $37(67)$ \\
\hline High & $10(19)$ & $4(7)$ & $3(6)$ & $10(19)$ & $3(5)$ & $\begin{array}{c}11 \\
(20)\end{array}$ & $12(22)$ & $2(3)$ & $14(25)$ & $0(0)$ & $3(5)$ & $10(18)$ & $7(12)$ & $8(14)$ \\
\hline \multicolumn{15}{|l|}{ HER-2 } \\
\hline Neg/Low & $41(74)$ & $38(69)$ & $\begin{array}{c}17 \\
(32)\end{array}$ & $\begin{array}{c}60 \\
(110)\end{array}$ & $\begin{array}{c}19 \\
(35)\end{array}$ & $\begin{array}{c}58 \\
(105)\end{array}$ & $\begin{array}{c}69 \\
(126)\end{array}$ & $8(15)$ & 68 (123) & $10(18)$ & $20(36)$ & $\begin{array}{c}57 \\
(102)\end{array}$ & $41(74)$ & $37(66)$ \\
\hline High & $13(24)$ & $8(15)$ & $6(11)$ & $17(31)$ & $5(9)$ & $\begin{array}{c}18 \\
(33)\end{array}$ & $19(35)$ & $4(7)$ & $18(32)$ & $5(9)$ & $5(9)$ & $18(32)$ & $14(26)$ & $8(15)$ \\
\hline
\end{tabular}




\begin{tabular}{|c|c|c|c|c|c|c|c|c|c|c|c|c|c|c|}
\hline Ki-67 & $P=$ & .048 & & & & & & & $P=$ & & & & & \\
\hline Neg/Low & $36(66)$ & $24(44)$ & $\begin{array}{c}17 \\
(31)\end{array}$ & $43(79)$ & $\begin{array}{c}14 \\
(25)\end{array}$ & $\begin{array}{c}46 \\
(85)\end{array}$ & $50(92)$ & $9(17)$ & $54(99)$ & $6(11)$ & $16(29)$ & $43(76)$ & $35(63)$ & $25(46)$ \\
\hline High & $18(32)$ & $22(40)$ & $7(12)$ & $34(63)$ & $\begin{array}{c}11 \\
(20)\end{array}$ & $\begin{array}{c}29 \\
(53)\end{array}$ & $38(70)$ & $3(5)$ & $31(56)$ & $9(16)$ & $9(16)$ & $32(58)$ & $21(38)$ & $19(35)$ \\
\hline
\end{tabular}

Fisher's exact test and chi-square test.
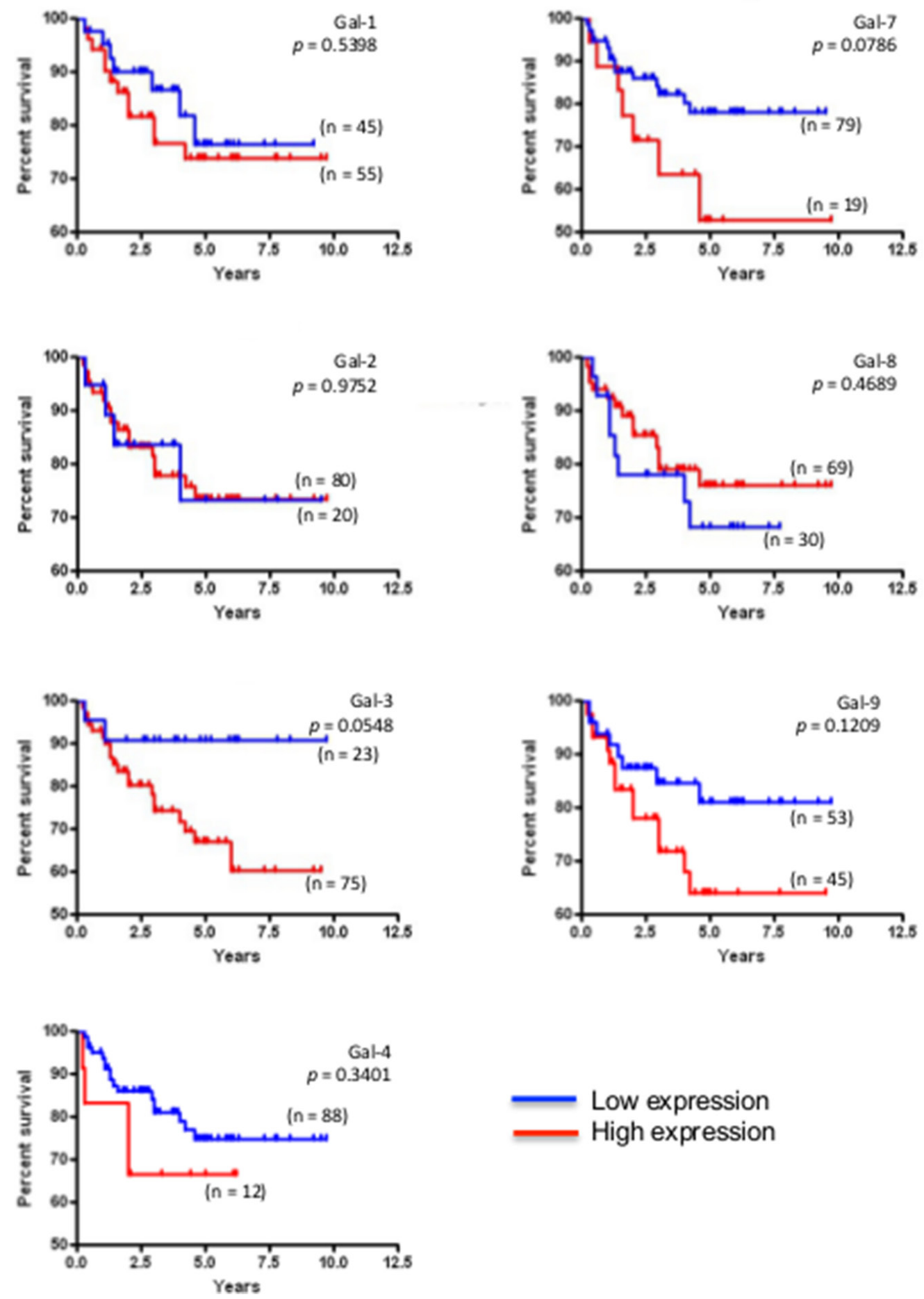

\section{Low expression}

High expression

Figure 5: Prognostic potential of galectin in across molecular subtypes of breast cancer. Kaplan-Meier estimates of 5-year DFS in breast cancer patients with low or high galectin expression independently of the molecular subtype. 
significant positive correlation between expressions of these galectins (Figure 10).

\section{DISCUSSION}

Triple-negative breast cancer is among the most aggressive breast cancer subtypes. To date, there is no clinically available targeted therapy for patients diagnosed with TNBC and approximately $30 \%$ of TNBC patients eventually experience distant relapse. The heterogeneity of TNBC makes predicting treatment difficult and remains a major obstacle for the development of TNBC-specific therapeutic targets. In this study, we report that specific

galectin expression signatures at the mRNA and protein levels contribute to the phenotypic heterogeneity of TNBC and segregate subsets of aggressive breast cancer into clinically meaningful subtypes.

Gene or protein expression signatures of cancer tissues are generally obtained from whole tumor homogenates, thus reflecting the expression from all cell types present in the tumor. Given the critical role stromal cells in cancer progression, several groups have thus looked at defining signatures that reflects expression profiles of for both cancer and stromal cells [23]. Such strategy has shown, for instance, that the molecular signature of an immune response is an important
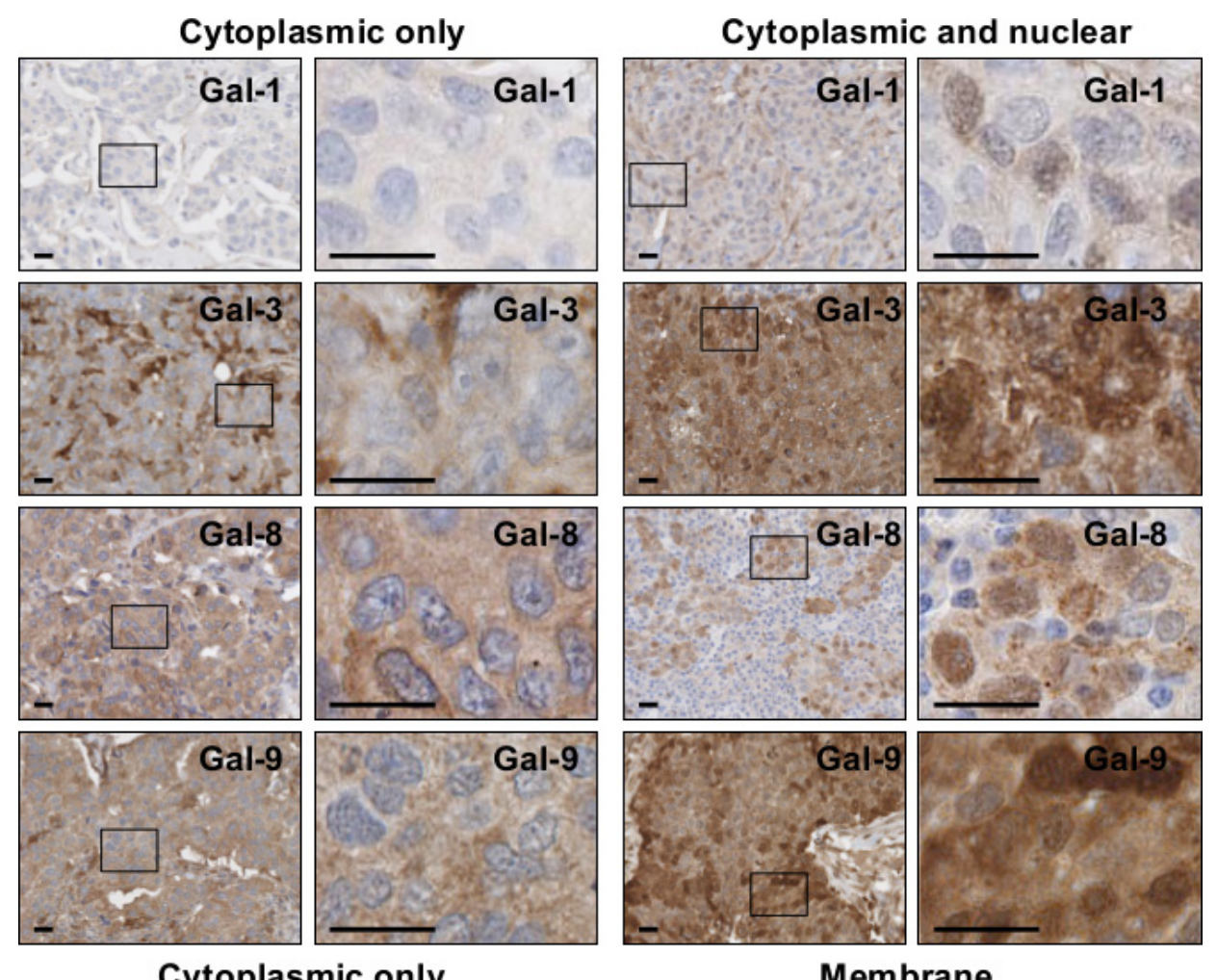

Membrane
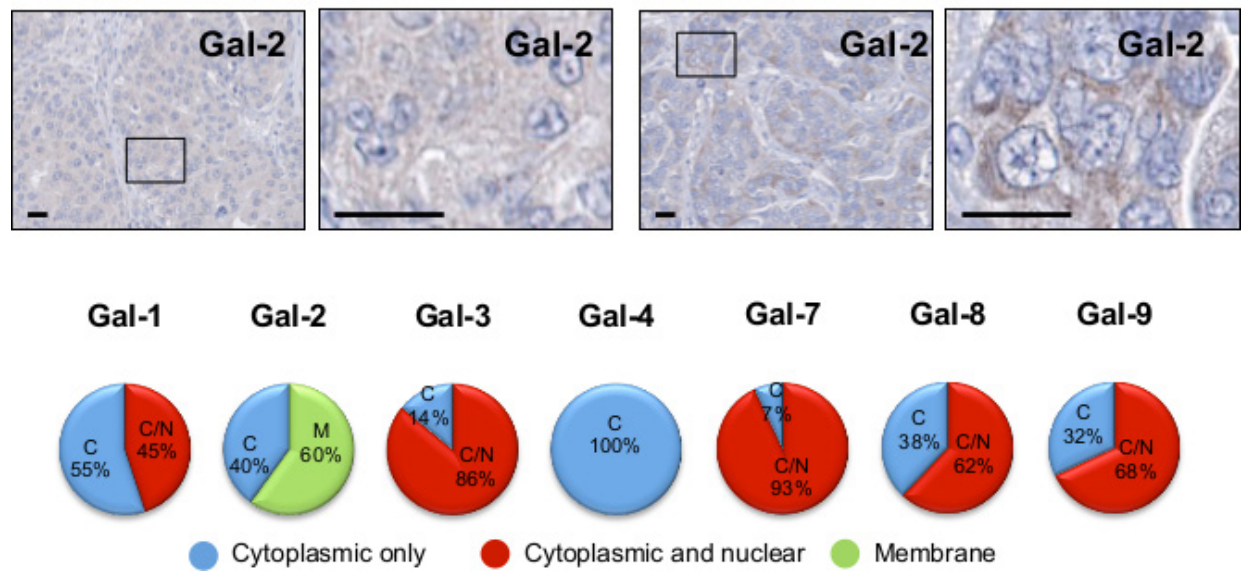

Figure 6: Subcellular localization of galectins in breast cancer tissues. Representative IHC stainings of galectin expression in breast cancer tissues. All scale bars, $25 \mu \mathrm{m}$. The lower circle graphs show the percentage of galectin-positive staining in the cytosol only $(\mathrm{C})$, at the membrane $(\mathrm{M})$ and in the cytosol and nuclei $(\mathrm{C} / \mathrm{N})$. 
Table 5: Histoclinical correlations of breast cancers according to galectins localization in cancer cells

\begin{tabular}{|c|c|c|c|c|c|c|c|c|c|c|}
\hline \multirow[t]{2}{*}{ Characteristics } & \multicolumn{2}{|c|}{ Gal-1 \% (n) } & \multicolumn{2}{|c|}{ Gal-2 \% (n) } & \multicolumn{2}{|c|}{ Gal-3 \% (n) } & \multicolumn{2}{|c|}{ Gal-8 \% (n) } & \multicolumn{2}{|c|}{ Gal-9 \% (n) } \\
\hline & $\mathrm{C}$ & $\mathbf{C} / \mathbf{N}$ & $\mathrm{C}$ & $\mathbf{M}$ & $\mathbf{C}$ & $\mathbf{C} / \mathbf{N}$ & $\mathbf{C}$ & $\mathbf{C} / \mathbf{N}$ & $\mathbf{C}$ & $\mathrm{C} / \mathrm{N}$ \\
\hline \multicolumn{11}{|l|}{ Age, yr } \\
\hline$\leq 45$ & $14(12)$ & $9(8)$ & $9(13)$ & $10(14)$ & $3(4)$ & $17(23)$ & $10(14)$ & $11(15)$ & $5(4)$ & $14(11)$ \\
\hline$>45$ & $41(35)$ & $36(31)$ & $31(43)$ & $50(71)$ & $11(15)$ & $69(96)$ & $27(37)$ & $52(70)$ & $27(22)$ & $54(44)$ \\
\hline Tumor volume & & & & & & & \multicolumn{2}{|c|}{$P=0.002$} & & \\
\hline$\leq 10 \mathrm{~cm}^{3}$ & $33(27)$ & $21(17)$ & $24(32)$ & $31(40)$ & $8(10)$ & $51(65)$ & $16(20)$ & $44(55)$ & $14(11)$ & $41(32)$ \\
\hline$>10 \mathrm{~cm}^{3}$ & $24(19)$ & $22(18)$ & $14(19)$ & $31(40)$ & $7(9)$ & $34(43)$ & $22(28)$ & $18(23)$ & $17(13)$ & $28(22)$ \\
\hline Lymph node metastasis & & & & & \multicolumn{2}{|c|}{$P=0.043$} & & & & \\
\hline Negative & $37(32)$ & $30(26)$ & $25(34)$ & $42(59)$ & $6(8)$ & $58(79)$ & $22(29)$ & $42(56)$ & $21(17)$ & $41(33)$ \\
\hline Positive & $18(15)$ & $15(13)$ & $16(22)$ & $17(24)$ & $8(11)$ & $28(39)$ & $16(22)$ & $20(27)$ & $11(9)$ & $27(22)$ \\
\hline SBR-EE Grade & & & \multicolumn{2}{|c|}{$P<0.0001$} & & & \multicolumn{2}{|c|}{$P=0.024$} & & \\
\hline I (low) & $6(5)$ & $4(3)$ & $12(15)$ & $2(3)$ & $1(1)$ & $21(27)$ & $2(3)$ & $15(18)$ & $1(1)$ & $15(11)$ \\
\hline III (high) & $46(37)$ & $44(35)$ & $28(36)$ & $58(76)$ & $14(18)$ & $64(84)$ & $35(44)$ & $48(60)$ & $30(22)$ & $54(40)$ \\
\hline Molecular subtypes & \multicolumn{2}{|c|}{$P=0.019$} & \multicolumn{2}{|c|}{$P<0.0001$} & & & \multicolumn{2}{|c|}{$P<0.0001$} & & \\
\hline Triple negative & $22(19)$ & $33(28)$ & $7(10)$ & $37(52)$ & $7(10)$ & $33(46)$ & $24(33)$ & $14(19)$ & $17(14)$ & $23(19)$ \\
\hline HER-2 positive & $9(8)$ & $6(5)$ & $11(15)$ & $8(11)$ & $4(5)$ & $16(23)$ & $6(8)$ & $14(19)$ & $6(5)$ & $12(10)$ \\
\hline Luminal A & $22(19)$ & $6(5)$ & $20(29)$ & $14(20)$ & $3(4)$ & $33(46)$ & $7(10)$ & $31(42)$ & $9(7)$ & $32(26)$ \\
\hline Luminal B & $1(1)$ & $1(1)$ & $2(3)$ & $1(2)$ & $0(0)$ & $4(5)$ & $0(0)$ & $4(5)$ & $0(0)$ & $0(0)$ \\
\hline ER expression & \multicolumn{2}{|c|}{$P=0.007$} & \multicolumn{2}{|c|}{$P=0.007$} & & & \multicolumn{2}{|c|}{$P=0.0003$} & & \\
\hline Neg/ Low & $33(28)$ & $40(34)$ & $21(30)$ & $45(64)$ & $11(15)$ & $55(77)$ & $30(41)$ & $30(41)$ & $23(19)$ & $38(31)$ \\
\hline High & $22(19)$ & $6(5)$ & $19(27)$ & $15(21)$ & $3(4)$ & $31(43)$ & $7(10)$ & $33(44)$ & $9(7)$ & $30(24)$ \\
\hline PR expression & & & \multicolumn{2}{|c|}{$P=0.042$} & & & & & & \\
\hline Neg/Low & $50(43)$ & $42(36)$ & $32(45)$ & $55(78)$ & $12(17)$ & $73(102)$ & $35(47)$ & $52(71)$ & $28(23)$ & $54(44)$ \\
\hline High & $5(4)$ & $3(3)$ & $8(12)$ & $5(7)$ & $1(2)$ & $13(18)$ & $3(4)$ & $10(14)$ & $4(3)$ & $14(11)$ \\
\hline HER-2 expression & & & \multicolumn{2}{|c|}{$P=0.023$} & & & & & & \\
\hline Neg/Low & $43(36)$ & $39(33)$ & $27(38)$ & $51(72)$ & $10(14)$ & $66(91)$ & $31(42)$ & $45(60)$ & $26(21)$ & $56(45)$ \\
\hline High & $11(9)$ & $7(6)$ & $13(18)$ & $9(13)$ & $4(5)$ & $20(28)$ & $6(8)$ & $18(24)$ & $6(5)$ & $12(10)$ \\
\hline EGFR expression & \multicolumn{2}{|c|}{$P=0.008$} & & & & & \multicolumn{2}{|c|}{$P=0.044$} & & \\
\hline Neg/ Low & $49(42)$ & $28(24)$ & $35(49)$ & $46(65)$ & $12(16)$ & $66(90)$ & $26(35)$ & $54(72)$ & $26(21)$ & $53(42)$ \\
\hline High & $6(5)$ & $17(14)$ & $6(8)$ & $13(19)$ & $2(3)$ & $20(28)$ & $11(15)$ & $9(12)$ & $6(5)$ & $15(12)$ \\
\hline Ki-67 expression & & & \multicolumn{2}{|c|}{$P=0.039$} & & & \multicolumn{2}{|c|}{$P=0.002$} & & \\
\hline Neg/Low & $33(28)$ & $19(16)$ & $27(38)$ & $29(41)$ & $8(11)$ & $54(74)$ & $15(20)$ & $42(56)$ & $16(13)$ & $41(33)$ \\
\hline High & $21(18)$ & $26(22)$ & 13 (19) & $31(44)$ & $6(8)$ & $33(45)$ & $23(31)$ & $20(27)$ & $16(13)$ & $27(22)$ \\
\hline
\end{tabular}

Fisher's exact test and chi-square test.

prognostic marker in breast cancer and in other cancer forms [23, 24]. Overall, we found that breast cancer stroma was rarely positive for gal-2, $-4,-7$, and 8 . In contrast, gal-1, -3, and -9-positive stroma were frequent, most notably in aggressive molecular subtypes. Interestingly, when released in the extracellular space, these galectins have been shown to contribute induce immune tolerance in various physiological and pathological processes. Such a role as alarmins for galectins has been well documented in pre-eclempsia for several members for the galectin family, including gal- $1,-3$, and -9 which have been shown to be up-regulated preeclamptic placentas [11, 25-28]. Galectins are also well known for key role in modulating local and systemic anti-tumor responses in cancer [29]. This has been particularly well described for gal-1, induces apoptosis of IFN- $\gamma$-producing cells and skews the tumor microenvironment toward a Th2 cytokine profile [30-33]. Gal-1 also contributes to the infiltration of 
IL-10-producing Treg1 cells to promote the tumor evasion [34]. In fact, we found that in some patients $(n=22)$, all three galectins are expressed in the stroma. Such triplepositive signature was exclusively found in high grade BC and in TNBC (77\%) or HER2 (23\%) molecular subtypes. Not surprisingly, 75\% (16/22) were expressing high levels of Ki-67-positive cells. These results suggest that stromal expression of gal-1, $-3,-9$ is associated with the most aggressive forms of breast cancer. This possibly explains why absence of gal-3 in preclinical mouse models of breast cancer does not alter tumor progression [35]. Future analyses with a higher number of patients will be needed to determine whether TNBC/HER2 patients that do express all three galectins in their stroma have a worst prognosis as patients than patients who do not express any or less than three of these galectins. It will also be interesting to identify stromal cells that express galectins and whether they do contribute to the presence of galectins in the extracellular space. Although our IHC staining does not allow to determine which galectins are released in the extracellular space and which cells are responsible for this secretion, historically, the presence of extracellular galectins has been attributed to cancer cells. We cannot exclude the possibility, however, that normal and/or

DFS- 5 years

$p=0.0243$

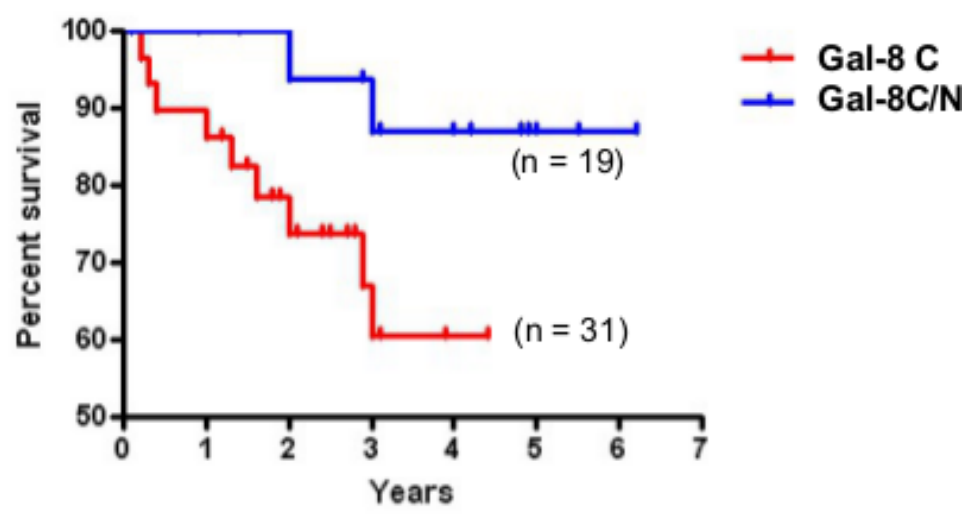

DDFS-5 years

$p=0.0019$

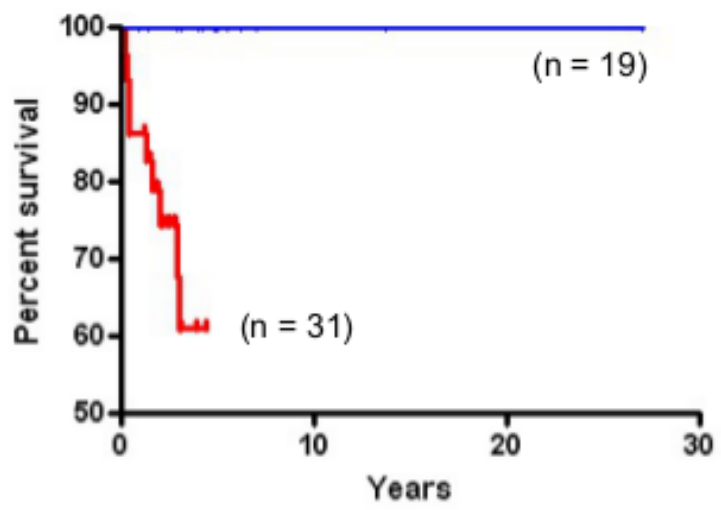

OS-5 years

$p=0.0292$

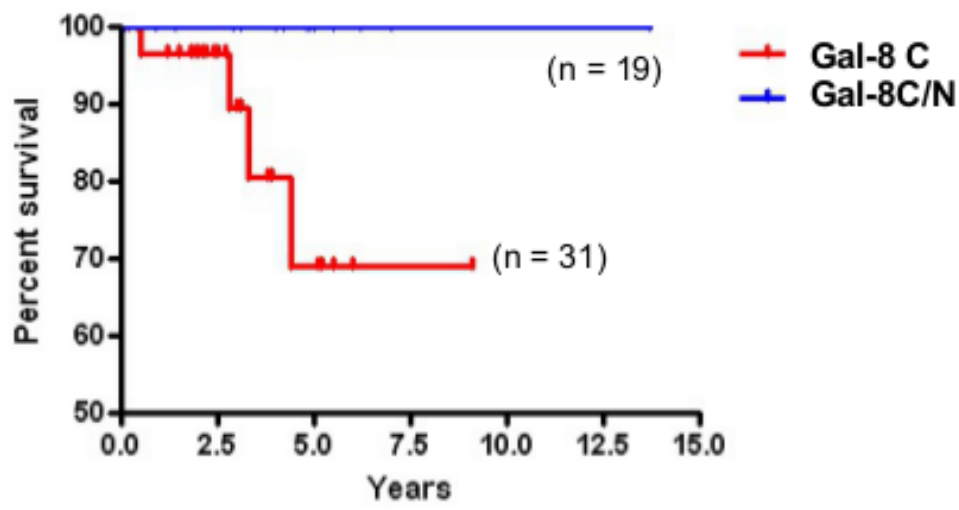

Figure 7: Prognostic potential of nuclear galectin-8 in TNBC. Kaplan-Meier estimates of 5-year DFS, DDFS, and OS in TNBC breast cancer patients expressing cytosolic $(\mathrm{C})$ or cytosolic and nuclear $(\mathrm{C} / \mathrm{N})$ galectin- 8 . 
cancer-associated stromal cells release soluble galectins. The presence of circulating levels of galectins in normal individuals certainly support sthis possibility. However, given the increasing evidence that intracellular galectins have many cellular functions and the strong cytosolic and nuclear staining that we observed in both cancer and stromal cells, we need to pay a particular attention to their role inside the cells. The emerging evidence that galectins have critical CRD-independent and intracellular functions certainly calls for a refocusing of our efforts on the development of new galectin-specific antagonists.

It is now well established that it is important to distinguish between stromal and tumor cell signatures to help in defining the heterogeneity of TNBCs and to identify new predictive tools and therapeutic targets. In our study, we have pushed this reasoning one step further by examining the subcellular compartmentalization of a galectins. Our approach was motivated by previous reports showing that members of the galectin family are well known for their heterogeneous pattern of expression and their wide range of biological functions, most notably as modulator of the immune response [29]. Overall, we found that galectins can be potential biomarkers of good and bad prognosis. Gal-1, -3, and -9 expressions in stroma or in tumor cells were all associated with a bad prognosis. Expression of gal-7 was also associated with a bad prognosis, as we previously reported [20]. In contrast to gal-1, -3 , and -9 , gal-7-positive staining was strictly found in the cytosol and nucleus of epithelial cells of approximately $25 \%$ of TNBC and HER2 molecular subtypes. It was not found in luminal A or B subtypes. In the case of gal-2, positive staining was found in all molecular subtypes but its membrane-associated form was also associated with a bad prognosis, as shown by its preferential association with TNBCs and Ki-67-positive staining. Gal-8 was the only galectin that we found was associated with a good prognosis. This association was observed when we took into consideration its nuclear localization in epithelial cells, which correlated with negative/low Ki-67 staining. Overall, these signatures are clearly different from that recently reported in the case of prostate cancer [36]. The authors found that gal-1 was the most abundantly expressed galectin in prostate cancer tissue. In contrast, other galectins (including gal-3, -4, -9, and 12) were expressed at lower levels whereas expression of gal-8 remained unchanged. Although the authors have not examined whether changes in subcellular localization or in the stromal cells occurred, these differences suggest that galectin signatures in cancer are tissue-specific and contributes to the heterogeneity of cancer (Figure 11).

Our results showing that nuclear gal-8 is associated with a good prognosis and that nuclear gal-1 is associated with a negative prognosis are eloquent examples of the importance of taking into account the subcellular localization of proteins with a wide range of subcellular localization. Interestingly, in patients that expressed both
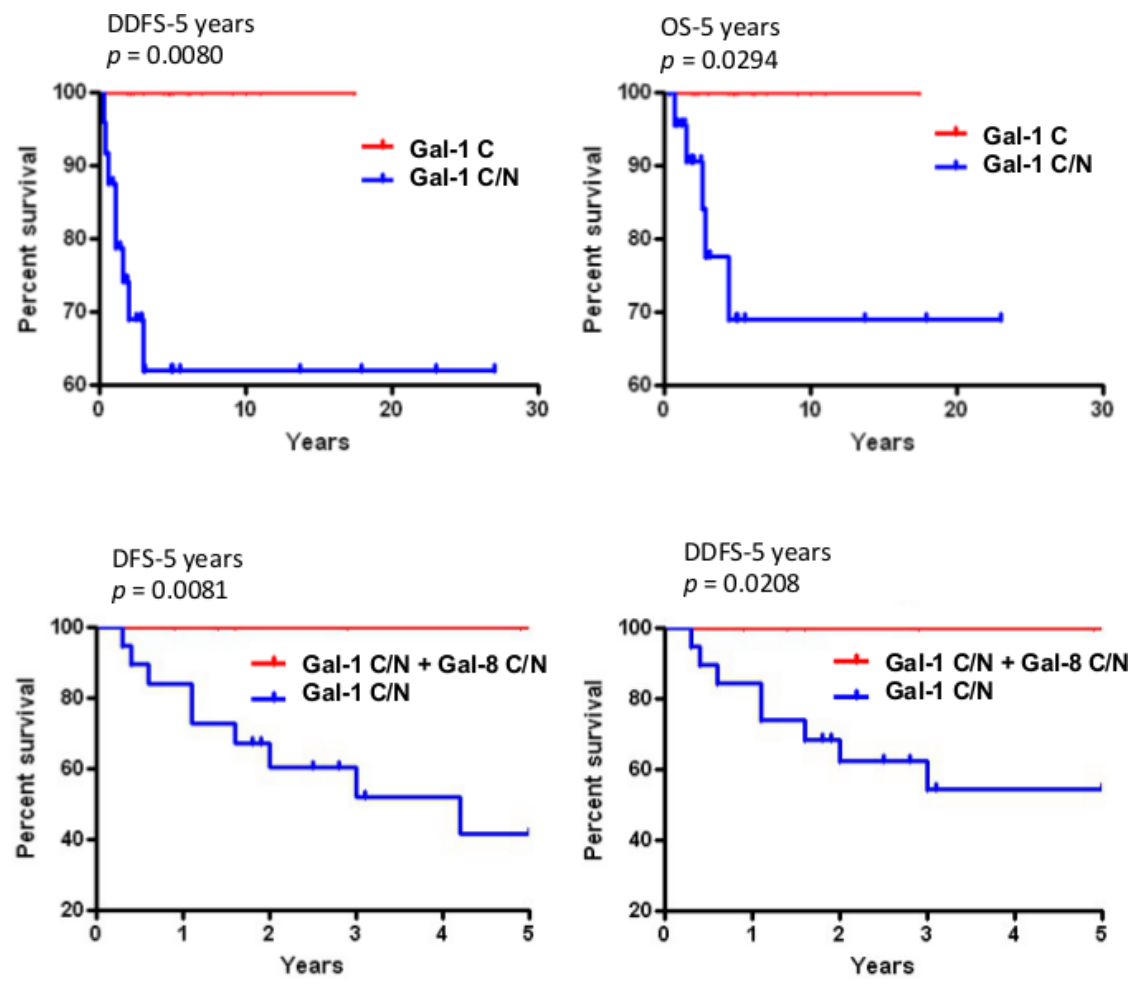

Figure 8: Prognostic potential of nuclear galectin-1 and -8. Upper histograms, Kaplan-Meier estimates of 5-year DDFS and $\mathrm{OS}$ in TNBC breast cancer patients expressing cytosolic (C) or cytosolic and nuclear (C/N) galectin-1. Lower histograms, Kaplan-Meier estimates of 5-year DDFS and DFS in breast cancer patients expressing nuclear galectin-1 and/or galectin- 8 . 
nuclear gal-1 and gal-8, the phenotype of gal- 8 was clearly dominant. Despite having nuclear gal-1, the 5-year survival rate of patients expressing nuclear gal-8 was $100 \%$. Such dominance for gal- 8 also suggests that both galectins have distinct (and contradictory) nuclear functions and that nuclear galectins undergo profound changes during cancer progression. These results uncover the clinical significance of nuclear gal-8 suspected from previous observations in normal and breast tissues [37]. Historically, gal-8 has been mostly recognized "matricellular extracellular protein" that mediates cell-matrix adhesion following binding to cell-surface integrins [38]. Although our approach is not sensitive enough to confirm the presence of gal-8 outside the cell surface, our data showing strong nuclear and cytosolic gal-8 is consistent with other reports that have shown that gal-8 shuttles between the nucleus and the cytosol in cancer cells [39]. Although the molecular mechanism regulating gal-8 (and gal-1) trafficking in the nucleus is currently unknown, it will be interesting to test whether karyopherins are involved. These proteins have
A

Gal-1

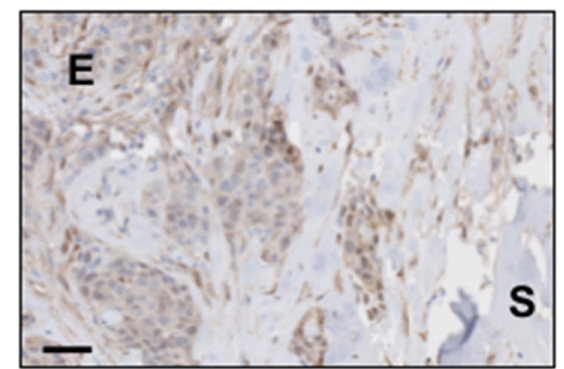

Gal-3

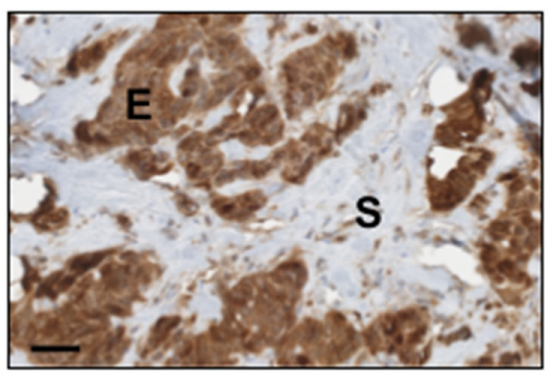

Gal-9

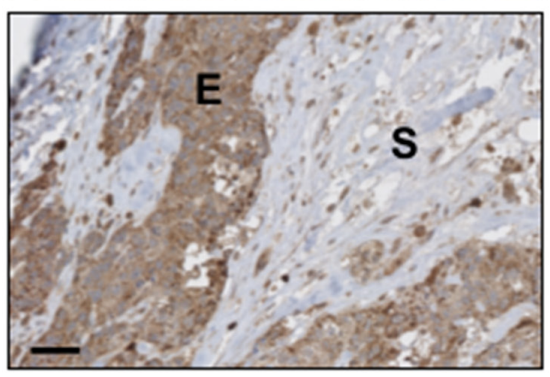

\section{Epithelial Neg/Low + Stromal High}
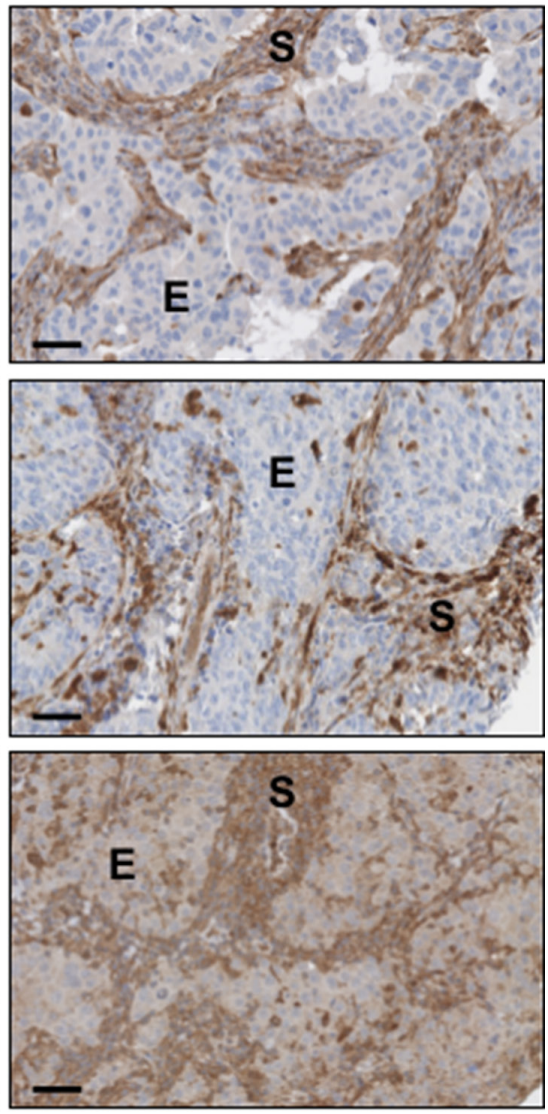

B

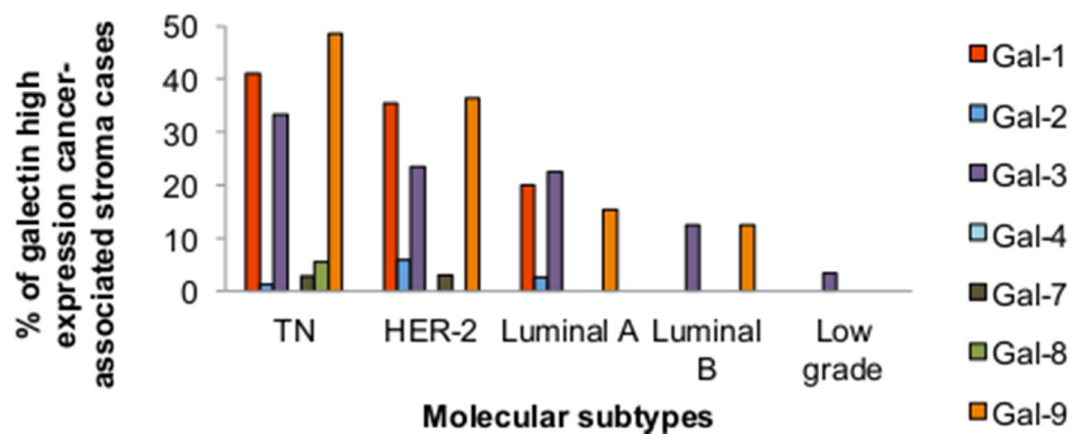

Figure 9: Stromal expression of galectins. (A) Representative IHC staining of galectin-1, -3, and -9 expression in epithelial (E) and stromal (S) cells in breast cancer tissues. All scale bars, $50 \mu \mathrm{m}$. (B) Bar histograms showing the percentage of cases with high levels of expression of stromal galectin-1, -3, and 9 in molecular subtypes. (C) Correlation between galectin-1, -3, and -9 expression in breast cancer tissues measured across the molecular subtypes. 
Table 6: Histoclinical correlations of breast cancers according to galectins expression in cancer-associated stroma

\begin{tabular}{|c|c|c|c|c|c|c|}
\hline \multirow{2}{*}{ Characteristics } & \multicolumn{2}{|c|}{ Gal-1 \% (n) } & \multicolumn{2}{|c|}{ Gal-3 \% (n) } & \multicolumn{2}{|c|}{ Gal-9 \% (n) } \\
\hline & Neg/Low & High & Neg/Low & High & Neg/Low & High \\
\hline \multicolumn{7}{|l|}{ Age, yr } \\
\hline$\leq 45$ & $16(30)$ & $3(6)$ & $15(28)$ & $4(7)$ & $15(27)$ & $6(10)$ \\
\hline$>45$ & $57(104)$ & $24(43)$ & $61(112)$ & $20(36)$ & $54(98)$ & $26(47)$ \\
\hline \multicolumn{7}{|l|}{ Tumor volume } \\
\hline$\leq 10 \mathrm{~cm}^{3}$ & $43(72)$ & $14(24)$ & $42(71)$ & $14(24)$ & $39(66)$ & $17(29)$ \\
\hline$>10 \mathrm{~cm}^{3}$ & $29(49)$ & $14(24)$ & $35(59)$ & $10(17)$ & $29(49)$ & $15(25)$ \\
\hline \multicolumn{7}{|l|}{ Lymph node metastasis } \\
\hline Negative & $48(85)$ & $17(31)$ & $48(85)$ & $16(28)$ & $42(74)$ & $21(38)$ \\
\hline Positive & $25(45)$ & $10(18)$ & $29(51)$ & $8(15)$ & $26(47)$ & $11(19)$ \\
\hline SBR-EE Grade & \multicolumn{2}{|c|}{$P<0.0001$} & \multicolumn{2}{|c|}{$P=0.003$} & \multicolumn{2}{|c|}{$P<0.0001$} \\
\hline I (low) & $19(32)$ & $0(0)$ & $17(29)$ & $1(1)$ & $18(30)$ & $1(1)$ \\
\hline III (high) & $54(92)$ & $28(47)$ & $60(102)$ & $23(39)$ & $51(87)$ & $31(53)$ \\
\hline Molecular subtypes & \multicolumn{2}{|c|}{$P=0.0001$} & \multicolumn{2}{|c|}{$P=0.0516$} & \multicolumn{2}{|c|}{$P<0.0001$} \\
\hline Triple negative & $23(43)$ & $16(30)$ & $26(48)$ & $13(24)$ & $19(35)$ & $20(37)$ \\
\hline HER-2 positive & $11(20)$ & $6(11)$ & $14(26)$ & $4(8)$ & $11(21)$ & $7(12)$ \\
\hline Luminal A & $35(64)$ & $4(8)$ & $33(60)$ & $5(10)$ & $34(63)$ & $4(7)$ \\
\hline Luminal B & $4(8)$ & $0(0)$ & $4(7)$ & $1(1)$ & $4(7)$ & $1(1)$ \\
\hline ER expression & \multicolumn{2}{|c|}{$P<0.0001$} & \multicolumn{2}{|c|}{$P=0.031$} & \multicolumn{2}{|c|}{$P<0.0001$} \\
\hline Neg/Low & $38(70)$ & $23(42)$ & $44(81)$ & $18(33)$ & $34(63)$ & 27(49) \\
\hline High & $35(65)$ & $4(7)$ & $33(60)$ & $5(10)$ & $34(63)$ & $4(8)$ \\
\hline PR expression & \multicolumn{2}{|c|}{$P=0.017$} & & & \multicolumn{2}{|c|}{$P=0.0005$} \\
\hline Neg/Low & $60(111)$ & $26(47)$ & 65 (119) & $22(40)$ & $55(101)$ & $31(56)$ \\
\hline High & $13(24)$ & $1(2)$ & $12(22)$ & $2(3)$ & $14(25)$ & $1(1)$ \\
\hline \multicolumn{7}{|l|}{ HER-2 expression } \\
\hline Neg/Low & $58(105)$ & $21(38)$ & $58(106)$ & $19(34)$ & $53(96)$ & $24(44)$ \\
\hline High & $15(28)$ & $6(11)$ & $18(33)$ & $5(9)$ & $16(28)$ & $7(13)$ \\
\hline EGFR expression & \multicolumn{2}{|c|}{$P=0.016$} & \multicolumn{2}{|c|}{$P=0.007$} & \multicolumn{2}{|c|}{$P<0.0001$} \\
\hline Neg/Low & 63 (114) & $19(34)$ & 65 (119) & $15(28)$ & $61(110)$ & $19(35)$ \\
\hline High & $10(18)$ & $8(15)$ & $11(20)$ & $8(15)$ & $7(13)$ & $12(22)$ \\
\hline Ki-67 expression & \multicolumn{2}{|c|}{$P=0.027$} & \multicolumn{2}{|c|}{$P=0.007$} & \multicolumn{2}{|c|}{$P=0.001$} \\
\hline Neg/Low & $48(87)$ & $13(23)$ & $50(92)$ & $10(18)$ & $47(85)$ & $13(24)$ \\
\hline High & $25(46)$ & $14(26)$ & $26(48)$ & $14(25)$ & $22(40)$ & $18(33)$ \\
\hline p53 expression & \multicolumn{2}{|c|}{$P=0.024$} & \multicolumn{2}{|c|}{$P=0.05$} & $P$ & \\
\hline Neg/Low & $57(103)$ & $16(29)$ & $59(107)$ & $14(26)$ & $53(96)$ & $18(33)$ \\
\hline High & $17(30)$ & $11(20)$ & $18(33)$ & $9(17)$ & $16(29)$ & $13(24)$ \\
\hline
\end{tabular}

Fisher's exact test and chi-square test.

been shown to regulate nucleus-cytoplasm transport of galectin-3 [40]. Gal-8, however, is possibly not the only members of the galectin family to be associated with a good prognosis in breast cancer. Preliminary in silico analysis using the bc-GenExMiner database shows that high expression of lgals12, lgals 13, and lgals 14 correlates with a good prognosis in LN-negative and luminal B patients (Supplementary Figure S5). Future work will be needed, however, to determine their expression patterns and the good prognostic potential at the protein level. 
Table 7: Histoclinical correlations of breast cancers according to galectins expression in cancer-associated stroma

\begin{tabular}{|c|c|c|c|}
\hline \multirow[b]{2}{*}{ Characteristics } & \multicolumn{2}{|c|}{ Gal-1 / Gal-3 / Gal-9 stromal expression } & \multirow[b]{2}{*}{$\boldsymbol{P}$} \\
\hline & $\begin{array}{c}\text { Negative } \\
n=104\end{array}$ & $\begin{array}{c}\text { Triple positive } \\
n=22\end{array}$ & \\
\hline Age, yr & & & 0.562 \\
\hline$\leq 45$ & $18 \%(22)$ & $2 \%(3)$ & \\
\hline$>45$ & $65 \%(81)$ & $15 \%(19)$ & \\
\hline Tumor volume & & & 0.466 \\
\hline$\leq 10 \mathrm{~cm}^{3}$ & $48 \%(55)$ & $9 \%(10)$ & \\
\hline$>10 \mathrm{~cm}^{3}$ & $34 \%(39)$ & $10 \%(11)$ & \\
\hline Lymph node metastasis & & & 1.000 \\
\hline Negative & $52 \%(63)$ & $12 \%(14)$ & \\
\hline Positive & $30 \%(36)$ & $7 \%(8)$ & \\
\hline SBR-EE grade & & & 0.003 \\
\hline I (low) & $24 \%(28)$ & $0 \%(0)$ & \\
\hline III (high) & $58 \%(67)$ & $18 \%(21)$ & \\
\hline Molecular subtype & & & $<0.0001$ \\
\hline Triple negative & $23 \%(29)$ & $13 \%(17)$ & \\
\hline HER-2 positive & $12 \%(15)$ & $4 \%(5)$ & \\
\hline Luminal A & $42 \%(53)$ & $0 \%(0)$ & \\
\hline Luminal B (HER-2+) & $5 \%(7)$ & $0 \%(0)$ & \\
\hline ER expression & & & $<0.0001$ \\
\hline Neg/Low & $41 \%(51)$ & $17 \%(22)$ & \\
\hline High & $42 \%(53)$ & $0 \%(0)$ & \\
\hline PR expression & & & 0.023 \\
\hline Neg/Low & $66 \%(83)$ & $17 \%(22)$ & \\
\hline High & $17 \%(21)$ & $0 \%(0)$ & \\
\hline HER-2 expression & & & 1.000 \\
\hline Neg/Low & $64 \%(80)$ & $14 \%(17)$ & \\
\hline High & $18 \%(22)$ & $4 \%(5)$ & \\
\hline EGFR expression & & & 0.0003 \\
\hline Neg/ Low & $72 \%(89)$ & $9 \%(11)$ & \\
\hline High & $10 \%(13)$ & $9 \%(11)$ & \\
\hline Ki-67 expression & & & 0.0005 \\
\hline Neg/ Low & $57 \%(71)$ & $5 \%(6)$ & \\
\hline High & $26 \%(32)$ & $13 \%(16)$ & \\
\hline p53 expression & & & 0.003 \\
\hline Neg/Low & $65 \%(81)$ & $8 \%(10)$ & \\
\hline High & $18 \%(22)$ & $10 \%(12)$ & \\
\hline
\end{tabular}

Fisher's exact test and chi-square test.

Our study is the first study that provides a detailed analysis of the galectin protein signature in molecular subtypes of breast cancer. This signature is clearly different from the mRNA signatures obtained from in silico analyses of public databases [41]. For example, our analysis using the bc-GenExMiner database shows that gal-1, -2, -3, -4, -7, -8, and -9 were all expressed at the mRNA level in breast tumor tissues and had a relatively similar distribution among the molecular subtypes. While such databases clearly helps in our understanding of breast 

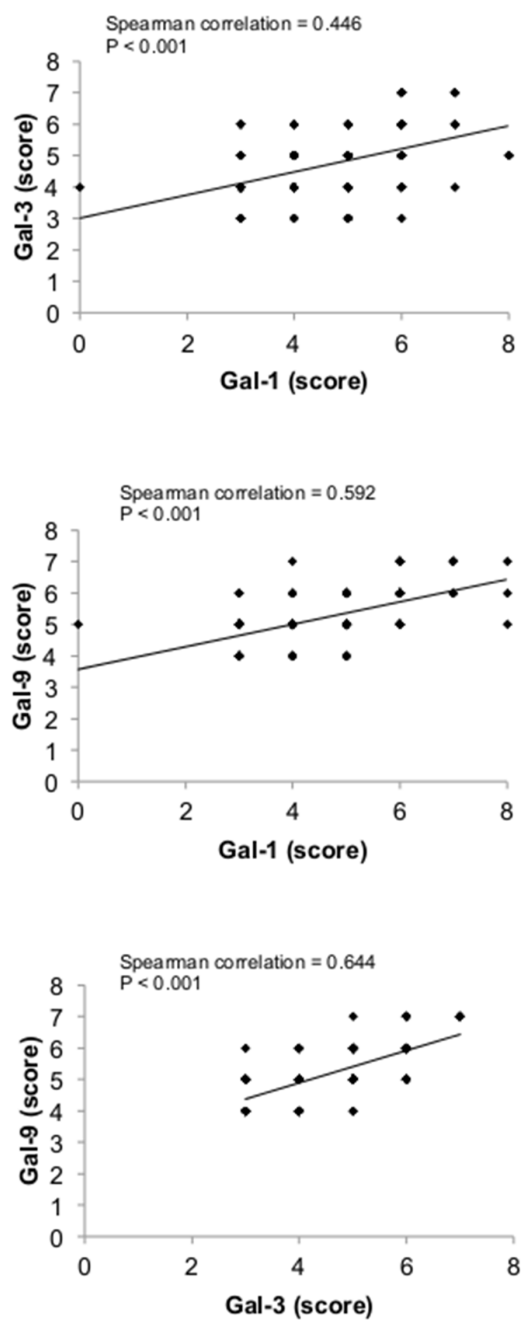

Figure 10: Correlation between galectin-1, -3 , and -9 expression in breast cancer tissues. Correlations were measured across the molecular subtypes.

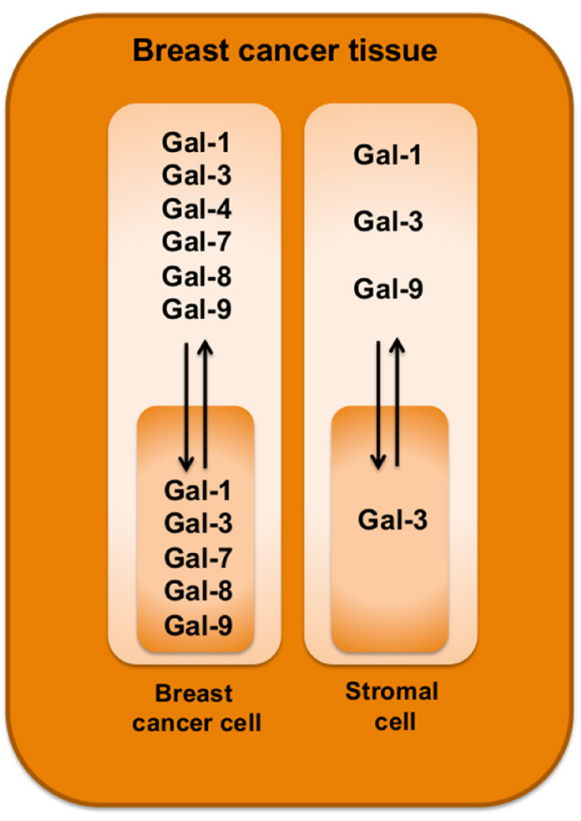

Figure 11: Schematic diagram highlighting galectin expression patterns in breast cancer tissues. 
cancer and facilitate the identification of novel intrinsic subtypes, caution should be exercised when evaluating the prognostic or therapeutic potential of a given gene, especially genes encoding multifunctional proteins like galectins. A case in point is the relevance of measuring cytoplasmic versus nuclear gal-8 or gal-1 staining. This is a critical issue given that a considerable amount of efforts are underway for the development of galectins inhibitors for the treatment of cancer.

\section{MATERIALS AND METHODS}

\section{In silico analysis}

The prognostic module of bc-GenExMiner v3.1 (Breast Cancer Gene-Expression Miner v3.1) [42] was used to correlate survival with each member of galectin family. Gene expression maps represent the percentage of patients with low, intermediate and high gene expression according to molecular subtypes. Kaplan-Meier survival curves (disease free, distance disease free and overall survival) of 4738 patients were obtained from the algorithm BreastMark [14] and the classifier PAM50 [15].

\section{Patients and tumor materials}

A cohort of 213 patients diagnosed with primary breast cancer between 2003 and 2008 at the Centre Hospitalier de l'Université de Montréal (CHUM) was used for the study. Tumors were selected on the basis of the histological diagnosis according to the classification of the Modified Scarff-Bloom-Richardson-Elston-Ellis grading system (SBR-EE) [43]. The cohort consisted of both low-grade and high-grade ductal carcinomas and of carcinomas with medullary features. Estrogen receptor status was positive in all low-grade carcinomas. This study was approved by the research ethics committee (CÉR) of the research centre at the CHUM (study SL05.019), in accordance with the Tri-Council Policy Statement on Research with Human Subjects. Consents directly from patients were not required in this study as per Ethics Board guidelines.

\section{Tissue microarrays and immunohistochemistry}

Formalin-fixed paraffin-embedded material from each primary tumor sample was used to construct tissue microarrays with an automated arrayer design to construct high-density tissue micro-array blocks (ATA-27 Beecher Instruments, Sun Prairie, WI). To that end, triplicate $1 \mathrm{~mm}$ cores from each tumor and control tissues were punched out and arrayed into six recipient blocks. For immunohistochemical analysis, threemicrometer thick sections were prepared from each TMA. Immunostaining reactions for each galectin were carried out using the Discovery XT automated immunostainer (Ventana Medical Systems, Tucson, AZ). Deparaffinized sections were incubated in cell conditioning $\mathrm{pH} 8$, except for anti-galectin-2 $(\mathrm{pH} 6)$, for antigen retrieval and then with primary antibodies for 1 to $3 \mathrm{hrs}$ : mouse monoclonal anti-galectin-1 (1:50; Novocastra, Leica Biosystems, Newcastle Upon Tyne, United Kingdom), rabbit polyclonal anti-galectin-2 (1:100; Proteintech Group, Chicago, IL, USA), rabbit monoclonal anti-galectin-3 (1:1000; Abcam, Cambridge, MA, USA), goat polyclonal anti-galectin-4 (1:200; Santa Cruz, Santa Cruz, CA, USA), goat polyclonal anti-galectin-7 (1:1000; R\&D Systems, Minneapolis, MN, USA), rabbit polyclonal anti-galectin-8 (1:50; Abcam) and rabbit polyclonal antigalectin-9 (1:100; Abcam). The slides were counterstained with hematoxylin and bicarbonate. Each section was scanned at a high resolution using the Nanozoomer Digital Pathology (Hamamatsu, Bridgewater, NJ). The validation of antibodies specificity was assessed using a tissue microarray of 21 different human normal tissues. Positive and negative controls were evaluated according to publications. The omission of the primary antibody was also used as a negative control. All antibodies were validated by their respective company and anti-galectin-1, 2, 3, 4 and 7 were used in previous publications [20, 44-49].

\section{Evaluation of immunohistochemical staining}

The percentage of staining was scored from 0 to 4 according to the percentage of positive cells displaying galectins expression within a sample (0 (0-9\%); 1 (10-25\%); 2 (26-50\%); 3 (51-75\%); 4 (76-100\%). The intensity of staining was also scored from 0 to 4 , with a score of 0 representing no staining and a score of 4 representing the strongest staining observed. Histological scores were calculated by adding both scores and a strong expression was defined by a score of 6 to 8 . This scoring system is somewhat comparable to the Allred score $[48,49]$.

\section{Statistical analysis}

Kaplan-Meier curves and relationship between proteins expression were assessed using GraphPad Prism 5.00 (GraphPad Software, San Diego, CA). For Fisher's exact test, chi-square test and spearman analysis, SPSS Statistics (IBM Corporation, Armoncon, NY) was used. A $P$ value of 0.05 or less was considered statistically significant.

\section{ACKNOWLEDGMENTS}

We thank Julie Hinsinger, Micheline Fortin, Mirela Birlea and Romain Sabina for their technical support at IRIC's histology core facility and Hugues Richard for assistance with statistical analyses. 


\section{GRANT SUPPORT}

Supported by grants to Y.S-P. from the National Science and Engineering Research Council of Canada (Grant No. 298215-2013). A.A.G. and M.L. are supported by a Ph.D. studentship from the Fonds de Recherche du Québec-Santé (FRQS).

\section{CONFLICTS OF INTEREST}

The authors declare that there is no conflicts of interest.

\section{REFERENCES}

1. Perou CM, Sorlie T, Eisen MB, van de Rijn M, Jeffrey SS, Rees CA, Pollack JR, Ross DT, Johnsen H, Akslen LA, Fluge O, Pergamenschikov A, Williams C, et al. Molecular portraits of human breast tumours. Nature. 2000; 406:747-752.

2. Sorlie T, Tibshirani R, Parker J, Hastie T, Marron JS, Nobel A, Deng S, Johnsen H, Pesich R, Geisler S, Demeter J, Perou CM, Lonning PE, et al. Repeated observation of breast tumor subtypes in independent gene expression data sets. Proc Natl Acad Sci U S A. 2003; 100:8418-8423.

3. Bedard PL, Hansen AR, Ratain MJ, Siu LL. Tumour heterogeneity in the clinic. Nature. 2013; 501:355-364.

4. Marusyk A, Tabassum DP, Altrock PM, Almendro V, Michor F, Polyak K. Non-cell-autonomous driving of tumour growth supports sub-clonal heterogeneity. Nature. 2014; 514:54-58.

5. Junttila MR, de Sauvage FJ. Influence of tumour microenvironment heterogeneity on therapeutic response. Nature. 2013; 501:346-354.

6. Garner OB, Baum LG. Galectin-glycan lattices regulate cell-surface glycoprotein organization and signalling. Biochem Soc Trans. 2008; 36:1472-1477.

7. Vladoiu MC, Labrie M, St-Pierre Y. Intracellular galectins in cancer cells: potential new targets for therapy (Review). Int J Oncol. 2014; 44:1001-1014.

8. Levi G, Teichberg VI. Isolation and physicochemical characterization of electrolectin, a beta-D-galactoside binding lectin from the electric organ of Electrophorus electricus. J Biol Chem. 1981; 256:5735-5740.

9. Barondes $\mathrm{SH}$, Castronovo V, Cooper DN, Cummings RD, Drickamer K, Feizi T, Gitt MA, Hirabayashi J, Hughes C, Kasai K, et al. Galectins: a family of animal betagalactoside-binding lectins. Cell. 1994; 76:597-598.

10. Liu FT, Rabinovich GA. Galectins as modulators of tumour progression. Nat Rev Cancer. 2005; 5:29-41.

11. Than NG, Romero R, Goodman M, Weckle A, Xing J, Dong Z, Xu Y, Tarquini F, Szilagyi A, Gal P, Hou Z, Tarca AL, Kim CJ, et al. A primate subfamily of galectins expressed at the maternal-fetal interface that promote immune cell death. Proc Natl Acad Sci U S A. 2009; 106:9731-9736.
12. Demotte N, Bigirimana R, Wieers G, Stroobant V, Squifflet JL, Carrasco J, Thielemans K, Baurain JF, Van Der Smissen P, Courtoy PJ, van der Bruggen P. A short treatment with galactomannan GM-CT-01 corrects the functions of freshly isolated human tumor-infiltrating lymphocytes. Clin Cancer Res. 2014; 20:1823-1833.

13. Cerliani JP, Dalotto-Moreno T, Compagno D, DerganDylon LS, Laderach DJ, Gentilini L, Croci DO, MendezHuergo SP, Toscano MA, Salatino M, Rabinovich GA. Study of galectins in tumor immunity: strategies and methods. Methods Mol Biol. 2015; 1207:249-268.

14. Madden SF, Clarke C, Gaule P, Aherne ST, O'Donovan N, Clynes M, Crown J, Gallagher WM. BreastMark: an integrated approach to mining publicly available transcriptomic datasets relating to breast cancer outcome. Breast Cancer Res. 2013; 15:R52.

15. Parker JS, Mullins M, Cheang MC, Leung S, Voduc D, Vickery T, Davies S, Fauron C, He X, Hu Z, Quackenbush JF, Stijleman IJ, Palazzo J, et al. Supervised risk predictor of breast cancer based on intrinsic subtypes. J Clin Oncol. 2009; 27:1160-1167.

16. Jung EJ, Moon HG, Cho BI, Jeong CY, Joo YT, Lee YJ, Hong SC, Choi SK, Ha WS, Kim JW, Lee CW, Lee JS, Park ST. Galectin-1 expression in cancer-associated stromal cells correlates tumor invasiveness and tumor progression in breast cancer. Int J Cancer. 2007; 120:2331-2338.

17. Hu Z, Fan C, Oh DS, Marron JS, He X, Qaqish BF, Livasy C, Carey LA, Reynolds E, Dressler L, Nobel A, Parker J, Ewend MG, et al. The molecular portraits of breast tumors are conserved across microarray platforms. BMC Genomics. 2006; 7:96.

18. Uhlen M, Oksvold P, Fagerberg L, Lundberg E, Jonasson K, Forsberg M, Zwahlen M, Kampf C, Wester K, Hober S, Wernerus H, Bjorling L, Ponten F. Towards a knowledgebased Human Protein Atlas. Nat Biotechnol. 2010; 28:1248-1250.

19. Uhlen M, Fagerberg L, Hallstrom BM, Lindskog C, Oksvold P, Mardinoglu A, Sivertsson A, Kampf C, Sjostedt E, Asplund A, Olsson I, Edlund K, Lundberg E, et al. Proteomics. Tissue-based map of the human proteome. Science. 2015; 347:1260419.

20. Demers M, Rose AA, Grosset AA, Biron-Pain K, Gaboury L, Siegel PM, St-Pierre Y. Overexpression of galectin-7, a myoepithelial cell marker, enhances spontaneous metastasis of breast cancer cells. Am J Pathol. 2010; 176:3023-3031.

21. Takenaka Y, Fukumori T, Yoshii T, Oka N, Inohara H, Kim HR, Bresalier RS, Raz A. Nuclear export of phosphorylated galectin-3 regulates its antiapoptotic activity in response to chemotherapeutic drugs. Mol Cell Biol. 2004; 24:4395-4406.

22. Boileau C, Poirier F, Pelletier JP, Guevremont M, Duval N, Martel-Pelletier J, Reboul P. Intracellular localisation of galectin-3 has a protective role in chondrocyte survival. Ann Rheum Dis. 2008; 67:175-181.

23. Finak G, Bertos N, Pepin F, Sadekova S, Souleimanova M, Zhao H, Chen H, Omeroglu G, Meterissian S, Omeroglu A, 
Hallett M, Park M. Stromal gene expression predicts clinical outcome in breast cancer. Nat Med. 2008; 14: 518-527.

24. Farmer P, Bonnefoi H, Anderle P, Cameron D, Wirapati P, Becette V, Andre S, Piccart M, Campone M, Brain E, Macgrogan G, Petit T, Jassem J, et al. A stroma-related gene signature predicts resistance to neoadjuvant chemotherapy in breast cancer. Nat Med. 2009; 15:68-74.

25. Jeschke U, Mayr D, Schiessl B, Mylonas I, Schulze S, Kuhn C, Friese K, Walzel H. Expression of galectin-1, -3 (gal-1, gal-3) and the Thomsen-Friedenreich (TF) antigen in normal, IUGR, preeclamptic and HELLP placentas. Placenta. 2007; 28:1165-1173.

26. Barrientos G, Freitag N, Tirado-Gonzalez I, Unverdorben L, Jeschke U, Thijssen VL, Blois SM. Involvement of galectin-1 in reproduction: past, present and future. Hum Reprod Update. 2014; 20:175-193.

27. Jeschke U, Hutter S, Heublein S, Vrekoussis T, Andergassen U, Unverdorben L, Papadakis G, Makrigiannakis A. Expression and function of galectins in the endometrium and at the human feto-maternal interface. Placenta. 2013; 34:863-872.

28. Miko E, Meggyes M, Bogar B, Schmitz N, Barakonyi A, Varnagy A, Farkas B, Tamas P, Bodis J, Szekeres-Bartho J, Illes Z, Szereday L. Involvement of Galectin-9/TIM-3 pathway in the systemic inflammatory response in early-onset preeclampsia. PLoS One. 2013; 8:e71811.

29. Rabinovich GA, Toscano MA. Turning 'sweet' on immunity: galectin-glycan interactions in immune tolerance and inflammation. Nat Rev Immunol. 2009; 9:338-352.

30. Perillo NL, Pace KE, Seilhamer JJ, Baum LG. Apoptosis of T cells mediated by galectin-1. Nature. 1995; 378:736-739.

31. Rubinstein N, Alvarez M, Zwirner NW, Toscano MA, Ilarregui JM, Bravo A, Mordoh J, Fainboim L, Podhajcer OL, Rabinovich GA. Targeted inhibition of galectin-1 gene expression in tumor cells results in heightened $\mathrm{T}$ cellmediated rejection; A potential mechanism of tumorimmune privilege. Cancer Cell. 2004; 5:241-251.

32. Stillman BN, Hsu DK, Pang M, Brewer CF, Johnson P, Liu FT, Baum LG. Galectin-3 and galectin-1 bind distinct cell surface glycoprotein receptors to induce T cell death. J Immunol. 2006; 176:778-789.

33. Juszczynski P, Ouyang J, Monti S, Rodig SJ, Takeyama K, Abramson J, Chen W, Kutok JL, Rabinovich GA, Shipp MA. The AP1-dependent secretion of galectin-1 by Reed Sternberg cells fosters immune privilege in classical Hodgkin lymphoma. Proc Natl Acad Sci U S A. 2007; 104:13134-13139.

34. Cedeno-Laurent F, Opperman M, Barthel SR, Kuchroo VK, Dimitroff CJ. Galectin-1 triggers an immunoregulatory signature in Th cells functionally defined by IL-10 expression. J Immunol. 2012; 188:3127-3137.

35. Eude-Le Parco I, Gendronneau G, Dang T, Delacour D, Thijssen VL, Edelmann W, Peuchmaur M, Poirier F. Genetic assessment of the importance of galectin-3 in cancer initiation, progression, and dissemination in mice. Glycobiology. 2009; 19:68-75.

36. Laderach DJ, Gentilini LD, Giribaldi L, Delgado VC, Nugnes L, Croci DO, Al Nakouzi N, Sacca P, Casas G, Mazza O, Shipp MA, Vazquez E, Chauchereau A, et al. A unique galectin signature in human prostate cancer progression suggests galectin-1 as a key target for treatment of advanced disease. Cancer Res. 2013; 73:86-96.

37. Danguy A, Rorive S, Decaestecker C, Bronckart Y, Kaltner H, Hadari YR, Goren R, Zich Y, Petein M, Salmon I, Gabius HJ, Kiss R. Immunohistochemical profile of galectin-8 expression in benign and malignant tumors of epithelial, mesenchymatous and adipous origins, and of the nervous system. Histol Histopathol. 2001; 16:861-868.

38. Levy Y, Arbel-Goren R, Hadari YR, Eshhar S, Ronen D, Elhanany E, Geiger B, Zick Y. Galectin-8 functions as a matricellular modulator of cell adhesion. J Biol Chem. 2001; 276:31285-31295.

39. Elola MT, Ferragut F, Cardenas Delgado VM, Nugnes LG, Gentilini L, Laderach D, Troncoso MF, Compagno D, Wolfenstein-Todel C, Rabinovich GA. Expression, localization and function of galectin- 8 , a tandem-repeat lectin, in human tumors. Histol Histopathol. 2014; 29:1093-1105.

40. Nakahara S, Hogan V, Inohara H, Raz A. Importin-mediated nuclear translocation of galectin-3. J Biol Chem. 2006; 281:39649-39659.

41. Miwa HE, Koba WR, Fine EJ, Giricz O, Kenny PA, Stanley P. Bisected, complex N-glycans and galectins in mouse mammary tumor progression and human breast cancer. Glycobiology. 2013; 23:1477-1490.

42. Jezequel P, Campone M, Gouraud W, Guerin-Charbonnel C, Leux C, Ricolleau G, Campion L. bc-GenExMiner: an easy-to-use online platform for gene prognostic analyses in breast cancer. Breast Cancer Res Treat. 2012; 131:765-775.

43. Elston CW, Ellis IO. Pathological prognostic factors in breast cancer. I. The value of histological grade in breast cancer: experience from a large study with long-term follow-up. Histopathology. 1991; 19:403-410.

44. de Vasconcelos Carvalho M, Pereira Jdos S, Alves PM, Silveira EJ, de Souza LB, Queiroz LM. Alterations in the immunoexpression of galectins-1, -3 and -7 between different grades of oral epithelial dysplasia. J Oral Pathol Med. 2013; 42:174-179.

45. Jung JH, Kim HJ, Yeom J, Yoo C, Shin J, Yoo J, Kang CS, Lee C. Lowered expression of galectin-2 is associated with lymph node metastasis in gastric cancer. J Gastroenterol. 2012; 47:37-48.

46. Wang LP, Chen SW, Zhuang SM, Li H, Song M. Galectin-3 accelerates the progression of oral tongue squamous cell carcinoma via a Wnt/beta-catenin-dependent pathway. Pathol Oncol Res. 2013; 19:461-474.

47. Tripodi D, Quemener S, Renaudin K, Ferron C, Malard O, Guisle-Marsollier I, Sebille-Rivain V, Verger C, Geraut C, Gratas-Rabbia-Re C. Gene expression profiling in sinonasal adenocarcinoma. BMC Med Genomics. 2009; 2:65. 
48. Allred DC, Harvey JM, Berardo M, Clark GM. Prognostic and predictive factors in breast cancer by immunohistochemical analysis. Mod Pathol. 1998; 11:155-168.

49. Mohsin SK, Weiss H, Havighurst T, Clark GM, Berardo M, Roanh le D, To TV, Qian Z, Love RR, Allred DC.
Progesterone receptor by immunohistochemistry and clinical outcome in breast cancer: a validation study. Mod Pathol. 2004; 17:1545-1554. 